\title{
Challenges of a Healthy Built Environment: Air Pollution in Construction Industry
}

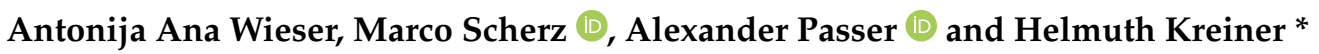 \\ Working Group Sustainable Construction, Institute of Technology and Testing of Construction Materials, \\ Graz University of Technology, Waagner-Biro-Straße 100/XI, 8020 Graz, Austria; \\ antonija.wieser@tugraz.at (A.A.W.); marco.scherz@tugraz.at (M.S.); alexander.passer@tugraz.at (A.P.) \\ * Correspondence: helmuth.kreiner@tugraz.at; Tel.: +43-(316)-873-7154
}

Citation: Wieser, A.A.; Scherz, M.;

Passer, A.; Kreiner, H. Challenges of a Healthy Built Environment: Air Pollution in Construction Industry. Sustainability 2021, 13, 10469. https:/ / doi.org/10.3390/su131810469

Academic Editors: Weixin Yang, Guanghui Yuan and Yunpeng Yang

Received: 20 July 2021

Accepted: 15 September 2021

Published: 21 September 2021

Publisher's Note: MDPI stays neutral with regard to jurisdictional claims in published maps and institutional affiliations.

\begin{abstract}
Air pollution is a global concern, especially in cities and urban areas, and has many implications for human health and for the environment. In common with other industrial sectors, the construction industry emits air pollutants. In scientific literature, the contribution the construction industry makes to air pollution is underexposed. This systematic literature review (SLR) paper gives an overview of the current literature regarding air pollution within the construction industry. Air pollution is discussed focusing mainly on three levels: (i) buildings and their building life cycle stages, (ii) construction processes and components, and (iii) building material and interior. The final sample of the SLR comprises 161 scientific articles addressing different aspects of the construction industry. The results show that most articles address the use stage of a building. Particulate matter in different sizes is the most frequently examined air pollutant within the SLR. Moreover, about a third of the articles refer to indoor air pollution, which shows the relevance of the topic. The construction industry can help to develop a healthier built environment and support the achievement of cleaner air within various life cycle stages, e.g., with optimized construction processes and healthier materials. International agreements and policies such as the Sustainable Development Goals (SDGs) can support the sustainable development of the construction industry.
\end{abstract}

Keywords: air pollution; construction industry; sustainable development goals; sustainable construction; healthy living environment

\section{Introduction}

Urbanization is a global megatrend. According to the United Nations (UN), around $68 \%$ of the world's population will live in cities and urban areas by 2050 [1]. Urban areas also need sustainable development, as reflected in the Sustainable Development Goals (SDGs), especially in SDG11 — Sustainable Cities and Communities. All UN member states have committed themselves to implement the global development agenda of the SDGs [2]. One of the issues reflected in the SDGs is air pollution. The importance of this is highlighted by its mention in the following SDG targets:

1. SDG target 3.9.: Reduce illnesses and deaths from hazardous chemicals and pollution;

2. SDG target 7.1.: Universal access to modern energy sources;

3. SDG target 11.6.: Reduce the environmental impacts of cities.

In target 11.6, emission-related environmental pollution is addressed via the indicator particulate matter with the indicator 11.6.2 Annual mean levels of fine particulate matter (e.g., PM2.5 and PM10) in cities (population weighted) [1].

Particulate matter (PM) is one of the most common air pollutants globally together with nitrogen oxides (NOx), photochemical oxidants incl. ozone (O3), carbon monoxide $(\mathrm{CO})$, lead $(\mathrm{Pb})$, and sulfur dioxides (SO2) [2]. Numerous people suffer from diseases such as acute respiratory diseases, chronic obstructive pulmonary disease, lung cancer, heart disease, and strokes due to air pollution. Others even die due to household and ambient 
air pollution and its consequences; the number of these fatalities was around 7 million in 2016 [3]. All regions worldwide are affected by air pollution, and the air pollution limits set by the World Health Organization (WHO) are met for only 9\% of the world's people [4]. Most at risk are people living in low- and middle-income countries, where $94 \%$ of all pollution-related deaths occur [5]. According to the European Environmental Bureau, air pollution is also the reason for over 400,000 premature deaths in the European Union (EU) [6]. In addition, the health-related economic cost of air pollution is estimated between 330 and 940 billion euros just for Europe [7].

Air pollutants occur e.g., not only in the transport, industry, or coal combustion sectors [6,8] but also in the construction sector [9-13]. Thereby pollutants have different sources of origin within the construction sector or the built environment. Outdoor sources include, e.g., construction activities, which can lead to dust production [14,15], or the use of construction machinery at sites [16,17], production of building materials [18,19], or pollutant emergence at other different life cycle stages of buildings such as the end-of-life stage $[20,21]$. Pollutants from indoor sources such as the emissions from glues and paints used for interiors [22], the emissions during cooking [23], heating [24,25], or the emissions caused by ventilation systems [26], however, are also of great significance in terms of air pollution.

Due to the authors' knowledge, there is no research article addressing explicitly construction industry and air pollution in a comprehensive way in just one literature review paper. Therefore, this article analyzes the air pollution caused by the construction industry and gives an outline of trends based on a systematic literature review (SLR). The aim is to determine the current state of research and thus to present an up-to-date status of current work in the field. The results of the article facilitate the work of researchers in this field in a new, comprehensive way and help to identify research gaps or further topics for discussion in this area. Four research questions (RQs) are addressed to achieve the defined goals:

- RQ1: How has the number of publications changed in recent years and in which regions are the most research results published? What are the scientific journals that cover the area of air pollution in the construction industry?

- RQ2: What have been the most widely used research designs in recent years that have been applied in current research practice in the field of air pollution in the construction industry?

- RQ3: What are the most addressed building types in current research on air pollution in the construction industry? Is a classification in detailed construction processes possible and how can the research articles be divided according to life cycle stages?

- RQ4: Is the current research focus on indoor or outdoor pollution? Which pollutants within the construction industry are the most addressed in the published scientific articles?

\section{Materials and Methods}

\subsection{Literature Selection}

By using the Preferred Reporting Items for Systematic reviews and Meta-Analyses (PRISMA) guideline, in this section, the literature selection with the method of systematic literature review (SLR) and its steps are presented.

2.1.1. Preferred Reporting Items for Systematic Reviews and Meta-Analyses (PRISMA) and Systematic Literature Review (SLR)

Following the reporting guideline PRISMA, an SLR about air pollution in the construction industry was conducted. The SLR is a systematic process for identifying relevant published sources in a special field to provide syntheses of the state of knowledge with the aim to identify future research priorities, to identify problems in primary research that should be addressed in future studies, or even for identifying relevant published sources to obtain a broad and comprehensive review of the literature that has been published for a given RQ [27-29]. While conducting the SLR and data analysis, the 27 items checklist 
of the PRISMA reporting guideline was followed to conduct a transparent, complete, and accurate review [27] shows the entire review process using the PRISMA flowchart.

\subsubsection{Search Strings and Constraints}

Referring to the formulated RQs, relevant search strings are identified and conducted in a scientific database. This article aims at answering the RQs mentioned in Section 1. In addition to the defined RQs, the starting point for the SLR is the definition of the keywords within the search strings. Based on the objectives of the research, the search strings consist of two term areas.

The database selected for the SLR was ScienceDirect. The search results were restricted to the English language only and excluded grey literature such as reports, books/chapters, conference papers, master's and/or doctoral theses. In addition, a constraint was set for the year of publication, which only includes articles in the period from January 2000 to April 2020. To avoid biases, all steps of the SLR were double-checked by the authors. The search strings used with the associated Boolean operators as well as the constraints are shown in Figure 1.

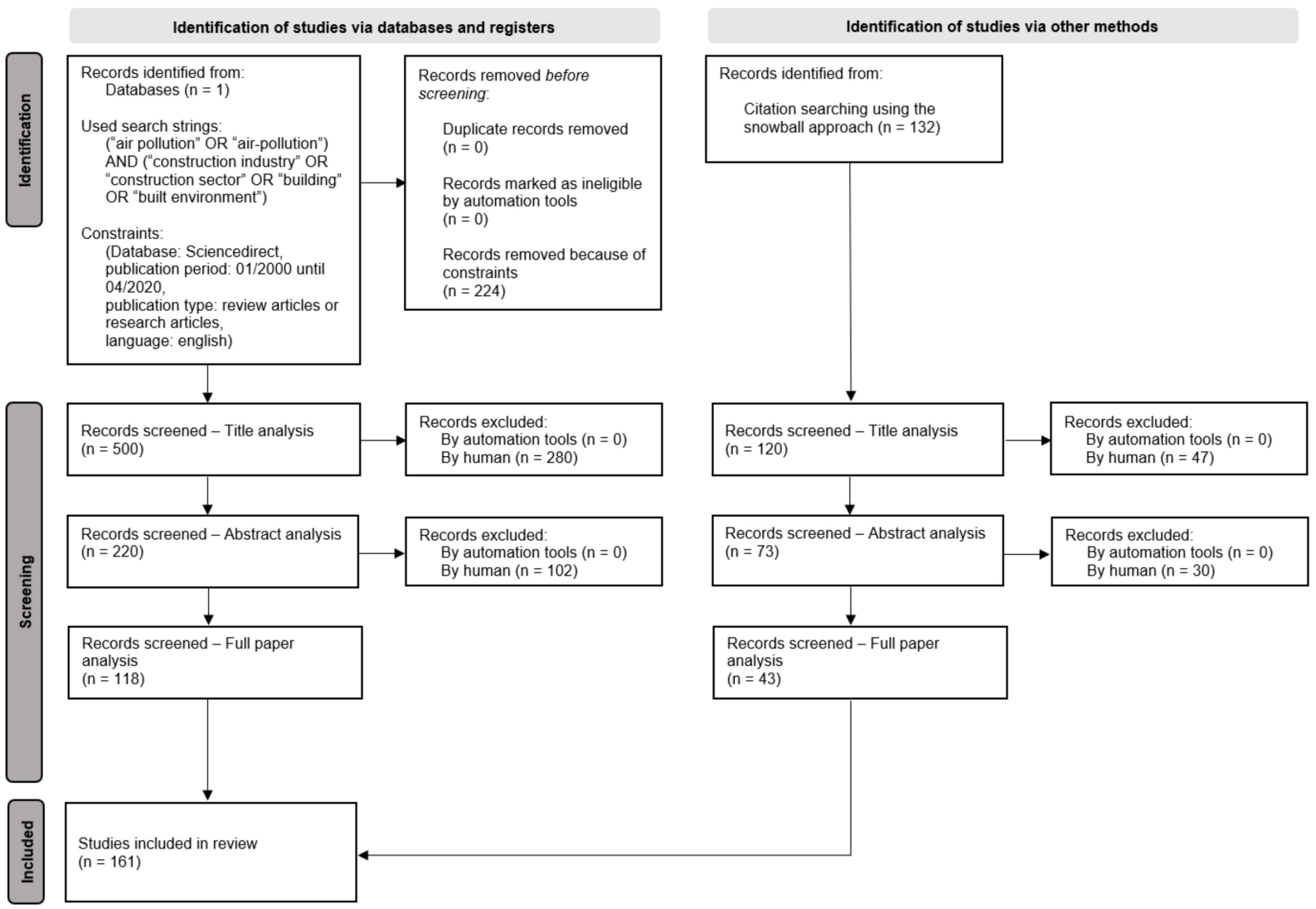

Figure 1. PRISMA 2020 flow diagram for new systematic reviews which included searches of databases, registers, and other sources supplemented by detailed information about the SLR and the snowball approach [27].

\subsubsection{Data Analysis and Research Approach}

As shown in Figure 1, the SLR results obtained after the first step were filtered in three further phases: (1) relevance by title, (2) relevance by abstract, and (3) relevance by full paper. In the first SLR phase, 724 papers were identified as relevant research articles. By filtering by title in phase two, the scope was limited to 500 papers. After reviewing the abstracts in phase three, 220 papers were left, and after reviewing the full papers in the last phase, 118 articles for in-depth analysis of papers were gathered. In addition, we collected further relevant literature using the "snowball" approach, proposed by Wohlin et al., by reviewing the references of the collected articles [29]. The identified research articles 
after applying the "snowball" approach were also sorted according to the three phases (title, abstract, full paper). After completion of the SLR and after applying the "snowball" approach, the final sample for the in-depth analysis included 161 records.

\subsection{Literature Background}

Air pollution is recognized as serious health and environmental problem for the world and as a strong risk factor for health [30]. Inhaling particulate matter (PM) of varying sizes, e.g., can lead to a range of health problems and early death [31]. It was estimated in 2017 that the cause of death for $8.7 \%$ of the world population was air pollution, meaning in total around 4.9 million deaths globally [32]. The global community thus has clear ambitions to improve the global situation with regard to cleaner air.

\subsubsection{Policies for Clean Air and Air Pollution Reduction}

Many different international institutions, organizations, and nation-states have issued policies and roadmaps to address this serious issue.

The United Nations Economic Commissions for Europe is addressing air pollution through the Geneva Convention on Long-range Transboundary Air Pollution; with this convention from 1979 health and environmental impact of air pollution should be reduced [33]. Another important resolution is the Stockholm Convention on Persistent Organic Pollutants, which was adopted in May 2001. Its goal is to restrict the use of persistent organic pollutants (POPs) [34].

On the EU level, an important regulation policy has been issued to reduce air pollution in the Clean Air Policy Package adopted in 2013, which was the result of the evaluation of the European air policy [35]. Amongst others, the Clean Air Policy Package included a proposal for the National Emission reduction Commitments directive [34,35]. Moreover, the Ambient Air Quality Directive and source-specific legislation also play an important role in European air-related policies and regulations [36,37].

The Agenda 2030 of the United Nations (UN), also known as the Sustainable Development Goals (SDGs), was adopted by the UN in 2015 [38]. SDG 3-Good health and well-being, SDG 7-Affordable and clean energy, SDG 11-Sustainable Cities and Communities, and SDG 13-Climate action are explicitly addressing the importance of reducing air pollution within their targets [33].

Moreover, the World Health Organization (WHO) has put in place the initiative The Global Platform on Air Quality and Health to build up capabilities for monitoring and assessing air pollution, enhance research and policies addressing and reducing air pollution and its health consequences [39]. Additionally, the WHO adopted the resolution Health and the environment: addressing the health impact of air pollution, and a draft road map for an enhanced global response to the adverse health effects of air pollution by its assembly in $2016[33,39]$.

In December 2017, the UN Environmental Assembly of the United Nations Environment Programme (UNEP) adopted the resolution for preventing and reducing air pollution to improve air quality globally $[40,41]$. The European Commission issued the Action Plan: "Towards a Zero Pollution for Air, Water and Soil" as part of the European Green Deal called Pathway to a Healthy Planet on 12 May 2021 [42,43]. The action plan is explicitly referred to air pollution in the context of buildings as well as indoor air quality.

Two further important global initiatives are the Climate and Clean Air Coalition to Reduce Short-Lived Climate Pollutants (CCAC) and the BreathLife campaign, issued by the WHO, CCAC, UNEP, and the World Bank [44,45].

\subsubsection{Air Pollutants}

The definition of limits for air pollution differs in various countries [46]. The present article has taken the six defined air pollutants of the U.S. Environmental Protection Agency (EPA) as the basis for air pollution categories applied for researching and categorizing literature within the SLR. According to the National Ambient Air Quality Standards of the 
EPA six pollutants are defined as air pollutants: carbon monoxide $(\mathrm{CO})$, lead $(\mathrm{Pb})$, nitrogen oxides (NOx, mainly nitrogen dioxide-NO2), photochemical oxidants (mainly groundlevel ozone, O3), particulate pollution (often referred to as particulate matter), and sulfur oxides (SOx, mainly sulfur dioxide (SO2) [2]. Furthermore, volatile organic compounds (VOC), ultrafine particulate matter (UFP), and ammonia were included in the article as significant pollutants because they often occur within a building, when addressing indoor air pollution.

Air pollution and climate change influence each other by complex correlations in the atmosphere. For example, increasing greenhouse gas (GHG) emissions (i.e., $\mathrm{CO}_{2}$-eq.) can lead to significantly higher ozone (O3) pollution in the future [47]. Moreover, Steinemann 2017 explicitly addressed climate change in combination with GHG emissions and their implications for indoor air quality in the context of green buildings [48]. The findings show that the link between air pollution and GHG emissions is complex and that there are various GHG emission effects on indoor air quality, whether on indoor pollutants themselves, building factors such as reduced ventilation rate, or behavior of occupants. In this context, many articles qualitatively describe the influence of air pollution on GHG emissions and often state that a reduction of air pollutants also reduces GHG emissions.

Detailed descriptions regarding the most common origin in general as well as about the effects of air pollutants can be found in [10,16,49-53].

\subsubsection{Outdoor (Ambient) Air Pollution}

Outdoor air pollution occurs in many different sectors, in cities, and in rural areas. Air pollution has various health implications for the global population and around 91\% of people on the globe are affected by air pollution according to WHO standards. The WHO thus suggests reducing air pollution by means of improvement measures in transport, energy-efficiency, power generation, industry, and municipal waste management in order to contribute to clean air and better air quality globally [54]. The EU Air quality in Europe-2020 report shows that the main emission sectors for air pollutions in Europe are (i) transport (road and non-road), (ii) the residential, commercial, institutional sector, (iii) energy supply, (iv) manufacturing and extractive industries (including heavy and light industry), (v) agriculture, and (vi) the waste sector (including wastewater management) [6].

\subsubsection{Indoor (Household) Air Pollution}

Indoor pollution plays an important role as people are spending most of their lifetime, according to studies up to $90 \%$, indoors $[55,56]$. In this context, the sick building syndrome describes health effects on occupants due to indoor air pollution and poor air quality during their time spent in buildings, respectively [12,57-60]. Indicators can be e.g., "complain of symptoms associated with acute discomfort, i.e., headache, eye, nose, or throat irritation; dry cough; dry or itchy skin; dizziness and nausea; difficulty in concentrating; fatigue; and sensitivity to odors". Causes can be inadequate ventilation, chemical contaminants from indoor or outdoor sources, or biological contaminants. Possible solutions and measures for better air quality within buildings can include the removal or modification of pollutants, higher ventilation rates, air cleaning, and education as well as better communication [61]. Further anthropogenic causes for indoor air pollution can include such important and essential everyday activities as cooking or heating with solid fuels (e.g., wood, charcoal, animal dung, etc.) [61,62].

\subsection{Air Pollution within the Construction Industry}

The construction industry emits air pollutants in various life cycle stages of buildings. In general, it can be stated that the construction industry causes both outdoor air pollution and indoor air pollution [17,57,63-65]. The construction sector is a major contributor to air pollution in different countries $[10,66,67]$, and a contributor to particulate matter pollution [10,68-70]. Air pollution emerges within the construction industry and occurs within all stages of the building life cycle according to EN 15804 and EN 15978 [71,72]. 
From the authors' point of view, the challenges should be differentiated according to production, construction, the end-of-life stage, and the use stage in the construction sector. Production, construction, and the end-of-life phase involve direct air pollution caused by, e.g., construction site works, construction site transports (fuel combustion and tire wear), or other dust generation. The construction sector is responsible for nearly $40 \%$ of global GHG emissions. Current studies have shown a significant air-pollutant potential (O3) induced by increasing $\mathrm{GHG}$ (i.e., $\mathrm{CO}_{2}$-eq.) emissions. In order to significantly reduce $\mathrm{GHG}$ emissions in the construction sector, for example, a growing number of countries have put in place policies to improve buildings' energy performance in recent years. However, a rapidly growing building sector, especially in developing countries, has offset those improvements. In other words, efficiency gains are not sufficient to compensate for the increase of total energy consumption caused by parameters as e.g., increasing population, increasing floor area, and/or other activities. To overcome these burdens a systemic view and consistency approach (instead of an efficiency approach) will urgently need to be considered in future policy strategies.

The European Parliament's EU policy on air quality presents policy measures for European cities to improve air quality. In the context of the construction industry and its contribution to air pollution, the energy efficiency of construction projects is outlined. Continuous improvement of the energy efficiency of buildings not only reduces the operating energy in the use phase but also tries to take into account the embodied energy from the manufacturing, construction, and deconstruction phases.

In the individual best practice recommendations of the European cities, measures for the construction site and for reducing air pollution during the construction and demolition of buildings are particularly relevant [73].

European guidelines do not specify mandatory construction requirements for individual air pollutants. However, a connection can be made through the mandatory energy standards [74]. In this context, according to the European Directive on the Energy Performance of Buildings (EPBD) new buildings in Europe may only be built to the lowest energy standard [75].

In addition to the building regulations in the individual countries, numerous building certification systems have been established in the last two decades, which, for instance, check criteria such as indoor air pollution or various environmental impacts as part of a life cycle assessment (LCA) on a voluntary basis.

\subsubsection{Product Stage (A1-A3)}

Within the product stage, air pollution can occur within the raw material supply, transport, or manufacturing. Additionally, the production of building, materials such as cement adds to air pollution and the emission of hazardous gases [19]. Within this stage transportation from the mining of raw materials to the production plant of building materials and their pollutants can also have an important role. In this context, construction machinery and the construction methods used in the extraction of raw materials, as well as the choice of transport vehicles (air pollution from fuel or tire abrasion), influence the effect on air pollution.

\subsubsection{Construction Process Stage (A4-A5)}

During the construction process stage, construction sites and construction-related traffic play a major role in air pollution. Construction activities and operations emit huge amounts of particles to the environment, putting both construction workers and people living in the surrounding construction sites at risk. Moreover, construction machinery and equipment can also add to air pollution at construction sites [17]. Part of the operation and supply of construction sites are traffic-related emissions [3]. 


\subsubsection{Use Stage (B1-B7)}

Buildings consume a lot of energy in their use stage and emit pollutants throughout this period. Heating, ventilation, and air-conditioning (HVAC) systems thus also play an important role within the use stage and can affect especially indoor air pollution.

Factors that additionally influence indoor air pollution concentrations are building physics and indoor airflows, ventilation rate, outdoor pollution concentration, and indoor emission sources [76]. Ruan and Rim state that the ventilation rate affects indoor air quality especially in polluted urban areas [17]. Furthermore, HVAC systems and their setup influence indoor air quality $[77,78]$.

Another source for indoor air pollution can be the material used and its specific functions or interior design, e.g., furniture or decoration [79]. Common indoor air pollution sources are household products, building materials, or plasticizers [57]. Depending on the different variables such as the choice of materials, material properties, and the material-specific function or material treatment (e.g., chemical treatments, coatings) the built substance itself can also release emissions and can considerably contribute to (indoor) air pollution [77]. Moreover, the right materials can also favor or reduce pollutants or even compensate and degrade them [80-82].

For a healthy living environment of tenants in terms of hygienic-sanitary conditions in the use stage, buildings and rooms need to be properly designed and executed as well as operated. Energy performance certificates could be a possible instrument to improve the regulations and energy management to better, comfortable, and healthy well-being of inhabitants as well as a better building performance. Another solution towards a healthier interior can be the application of evaluation and monitoring [83].

\subsubsection{End-of-Life Stage (C1-C4)}

After the use stage of the buildings, building materials, e.g., after demolition, can be recycled and used in a second (building) life cycle [84]. In practice, however, challenges regarding circularity and recycling still need to be solved [85]. Moreover, transport is also a source of pollution in the end-of-life stage of buildings. Additionally, air pollutants can be emitted during de-construction or the demolition of buildings and infrastructure, respectively $[69,86]$. Proper demolition management can decrease air pollution $[10,87]$.

\section{Results}

\subsection{Development of Publications over Time (RQ1)}

To give an introductory (metadata) overview of the chronological development of the research area as well as the geographical distribution of the universities investigating the addressed research area, the articles were analyzed by their year of publication and by the affiliation of the first author. In Figure 2, the number of published research articles in the field of air pollution in the construction industry according to the publication year is presented. There is a rising trend of relevant research articles published on the topic of air pollution in the construction industry. The number of research articles published rose from two in 2001 to a total of 161 by the end of April 2020. In the years 2001 to 2011, the number of published research articles identified as relevant within the SLR in the field was less than six research articles per year. In the years 2012 to 2020 publications continued to increase regularly. This trend clearly shows the increase in relevance of the topic of air pollution within the construction sector. 


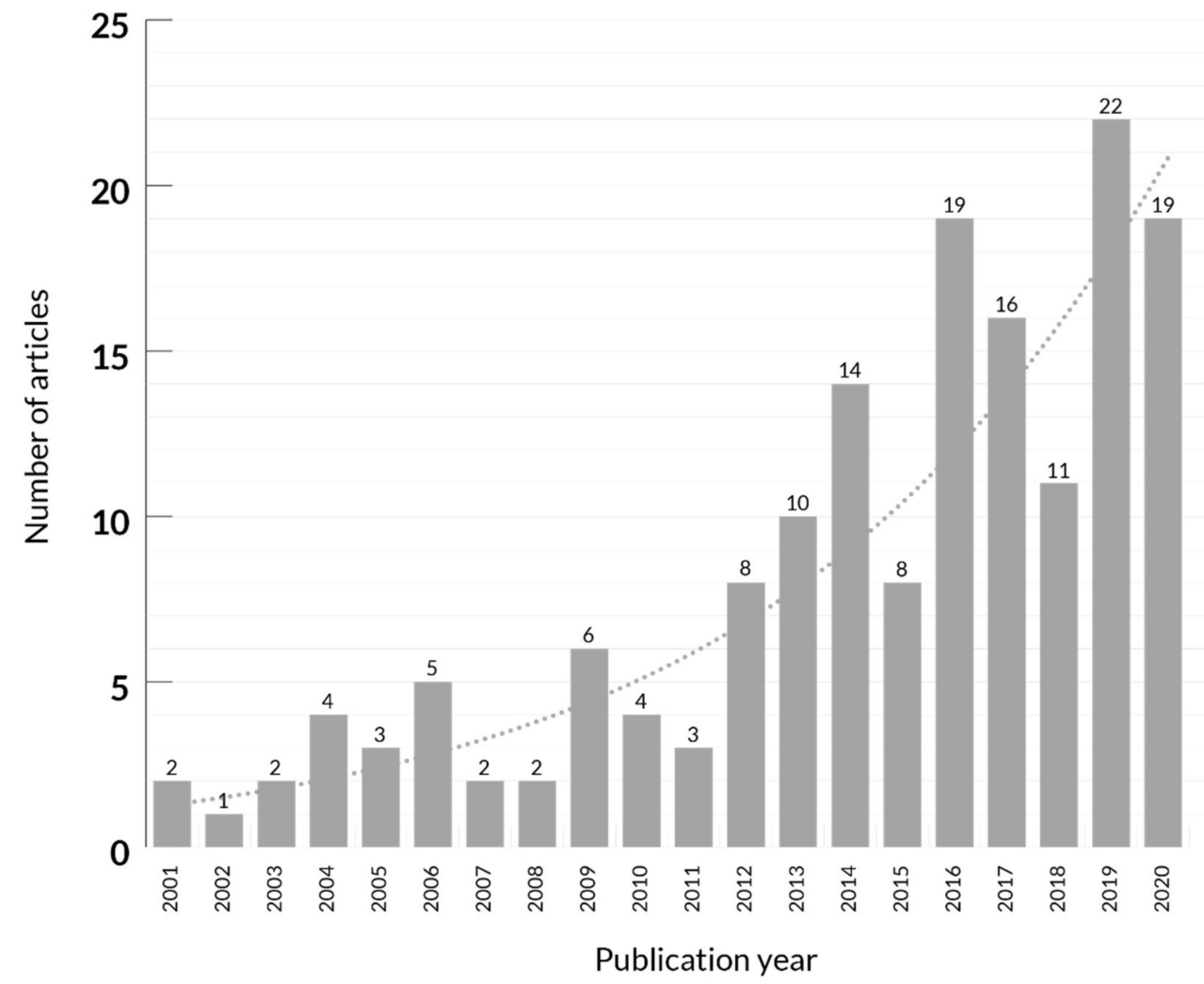

Figure 2. Development of published research articles in the field of air pollution and construction within the last years (until April 2020).

\subsection{Geographic Distribution of Publications (RQ1)}

Figure 3 presents the geographic distribution of the first author's affiliation on a world map. Most articles of the conducted SLR are published by authors from universities in China (36), in the United States (19), the United Kingdom (10), in Germany (9), Italy (9), and Hong Kong (6). It can be deduced that countries facing the challenge of air pollution, such as China, the United States, and the United Kingdom, are also publishing more scientific articles about air pollution in the construction industry.

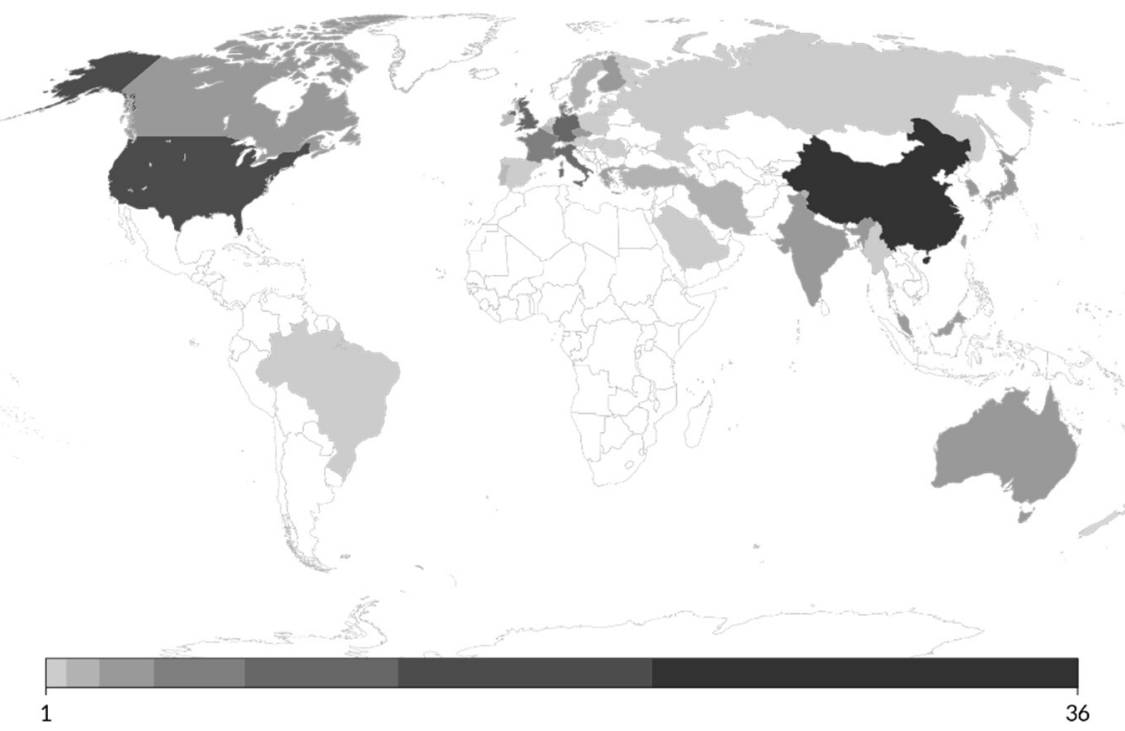

Figure 3. Geographic distribution of published articles by first author's affiliation. 


\subsection{Distribution by Publication Journal (RQ1)}

For the identification of scientific journals that frequently address and support the mentioned field of research, the research articles are classified by journals. This representation supports prospective scientists in their search for suitable journals in context with the addressed research area. In Table 1, the distribution of articles on air pollution in the construction industry according to the publication journals is shown.

Table 1. Overview of research articles and their distribution by publication journals.

\begin{tabular}{|c|c|c|c|}
\hline No. & Journal Title & Amount & $(\%)$ \\
\hline 1 & Building and Environment & 29 & 18.0 \\
\hline 2 & Atmospheric Environment & 18 & 11.2 \\
\hline 3 & Science of the Total Environment & 16 & 9.3 \\
\hline 4 & Journal of Cleaner Production & 9 & 5.6 \\
\hline 5 & Energy and Buildings & 6 & 3.7 \\
\hline 6 & Environmental Pollution & 5 & 3.1 \\
\hline 7 & Sustainable Cities and Society & 5 & 3.1 \\
\hline 8 & Environment International & 4 & 2.5 \\
\hline 9 & Indoor Air & 4 & 2.5 \\
\hline 10 & Procedia Engineering & 4 & 2.5 \\
\hline 11 & Sustainability & 4 & 2.5 \\
\hline 12 & Applied Energy & 3 & 1.9 \\
\hline 13 & Energy & 3 & 1.9 \\
\hline 14 & Energy Procedia & 3 & 1.9 \\
\hline 15 & Journal of Environmental Management & 3 & 1.9 \\
\hline 16 & Journal of the Air \& Waste Management Association & 3 & 1.9 \\
\hline 17 & Renewable and Sustainable Energy Reviews & 3 & 1.9 \\
\hline 18 & Urban Forestry \& Urban Greening & 3 & 1.9 \\
\hline 19 & American Society of Civil Engineers & 2 & 1.2 \\
\hline 20 & Atmospheric Pollution Research & 2 & 1.2 \\
\hline 21 & Construction and Building Materials & 2 & 1.2 \\
\hline 22 & Ecotoxicology and Environmental Safety & 2 & 1.2 \\
\hline 23 & Environmental Research & 2 & 1.2 \\
\hline 24 & Journal of Building Engineering & 2 & 1.2 \\
\hline 25 & Journal of Hazardous Materials & 2 & 1.2 \\
\hline 26 & Acta Polytechnica Hungarica & 1 & 0.6 \\
\hline 27 & APCBEE Procedia & 1 & 0.6 \\
\hline 28 & Applied Geography & 1 & 0.6 \\
\hline 29 & Atmospheric Environment & 1 & 0.6 \\
\hline 30 & Atmospheric Research & 1 & 0.6 \\
\hline 31 & Chemosphere & 1 & 0.6 \\
\hline 32 & Ecological Indicators & 1 & 0.6 \\
\hline 33 & Energy Conversion and Management & 1 & 0.6 \\
\hline 34 & Energy Policy & 1 & 0.6 \\
\hline 35 & Environmental Chemistry Letters & 1 & 0.6 \\
\hline 36 & Environmental Monitoring and Assessment & 1 & 0.6 \\
\hline 37 & Environmental Modelling \& Software & 1 & 0.6 \\
\hline 38 & Environmental Science \& Policy & 1 & 0.6 \\
\hline 39 & Environmental Science \& Technology & 1 & 0.6 \\
\hline 40 & Frontiers of Environmental Science \& Engineering & 1 & 0.6 \\
\hline 41 & IFAC PapersOnLine & 1 & 0.6 \\
\hline 42 & Indoor Built Environ & 1 & 0.6 \\
\hline 43 & $\begin{array}{c}\text { International Journal of Hygiene and Environmental } \\
\text { Health }\end{array}$ & 1 & 0.6 \\
\hline 44 & Journal of Environmental Engineering & 1 & 0.6 \\
\hline 45 & Journal of Cultural Heritage & 1 & 0.6 \\
\hline 46 & Journal of Transport \& Health & 1 & 0.6 \\
\hline 47 & Safety Science & 1 & 0.6 \\
\hline 48 & Urban Climate & 1 & 0.6 \\
\hline Total & & 161 & 100.0 \\
\hline
\end{tabular}


Most of the reviewed research articles were published in the scientific journals Building and Environment (29), Atmospheric Environment (18), and Science of the Total Environment (16). Nine articles were published in the Journal of Cleaner Production, six in Energy and Buildings, and five in the Journal Environmental Pollution and Sustainable Cities and Society. Environment International, Indoor Air, Procedia Engineering, Sustainability followed by four published research articles each.

\subsection{Research Designs for Air Pollution Research in Construction Industry (RQ2)}

In this $R Q$, the articles of the final sample are classified according to research designs and an overview of applied methods is presented. Therefore, the articles were assigned to the defined research designs in Table 2.

Table 2. Overview of research designs.

\begin{tabular}{|c|c|}
\hline Research Design & Description \\
\hline Literature reviews & $\begin{array}{l}\text { With the application of a literature overview in the study, a summary of the most } \\
\text { relevant scientific literature to the research topic of the study is provided. Moreover, an } \\
\text { introductory chapter with literature references is also considered as a literature review. }\end{array}$ \\
\hline Measurement/Method development & $\begin{array}{l}\text { Measurements of the air pollutants that occur are conducted in various experimental } \\
\text { and study setups. Moreover, the theoretical development of existing methods, } \\
\text { methodological approaches, or measurement instruments can be advanced to improve } \\
\text { existing (evaluation) methods, methodologies, or measurement instruments. }\end{array}$ \\
\hline Model development & $\begin{array}{l}\text { The development of modeling approaches for air pollution are advanced in the course } \\
\text { of the study to improve existing models. }\end{array}$ \\
\hline $\begin{array}{l}\text { Case study } \\
\text { (field experiment) }\end{array}$ & $\begin{array}{l}\text { The subject of the study is demonstrated resp. tested with specific case studies, using } \\
\text { (field) experiments on-site to test the hypothesis resp. to answer the research } \\
\text { question(s) posed. }\end{array}$ \\
\hline Case studies based on virtual simulation & $\begin{array}{l}\text { The topic of the study is demonstrated resp. tested, with specific case studies based on } \\
\text { virtual simulations (such as air flow simulations) to test the hypothesis resp. answer } \\
\text { the research question(s). }\end{array}$ \\
\hline Surveys & $\begin{array}{l}\text { The study method comprises the conducting of a survey, meaning the relevant topic is } \\
\text { examined through a series of questions (=questionnaire) and sent out to the } \\
\text { appropriate target group to receive answers and, therefore, results. }\end{array}$ \\
\hline Interviews & $\begin{array}{l}\text { The study method is conducting interviews (e.g., with experts, semi-structured or } \\
\text { guideline-based interviews). }\end{array}$ \\
\hline Other methods & $\begin{array}{l}\text { All other methods and methodologies which are not mentioned above are subsumed } \\
\text { within this category. }\end{array}$ \\
\hline
\end{tabular}

Figure 4 presents a pie-chart with the number of published research articles assigned to different research designs.

Some of the research articles are based on several research designs. Since multiple answers were possible, the sum of the research articles in the pie chart $(n=345)$ exceeded the number of identified articles $(n=161)$. On this basis, $35 \%$ of reviewed research articles can be classified in the category Case study (field experiment), and 28\% used Measurement/Method development to reach their results and findings. In about 10\% of the articles Model development was used and in $9 \%$ Case studies based on virtual simulation were the preferred research design. Literature reviews were conducted in 7\% of the overall sample of the SLR and $4 \%$ used surveys as their research design. $1 \%$ of the research articles chose interviews as their preferred research design and 1\% used other methods, which cannot be assigned to any of the defined research designs. 


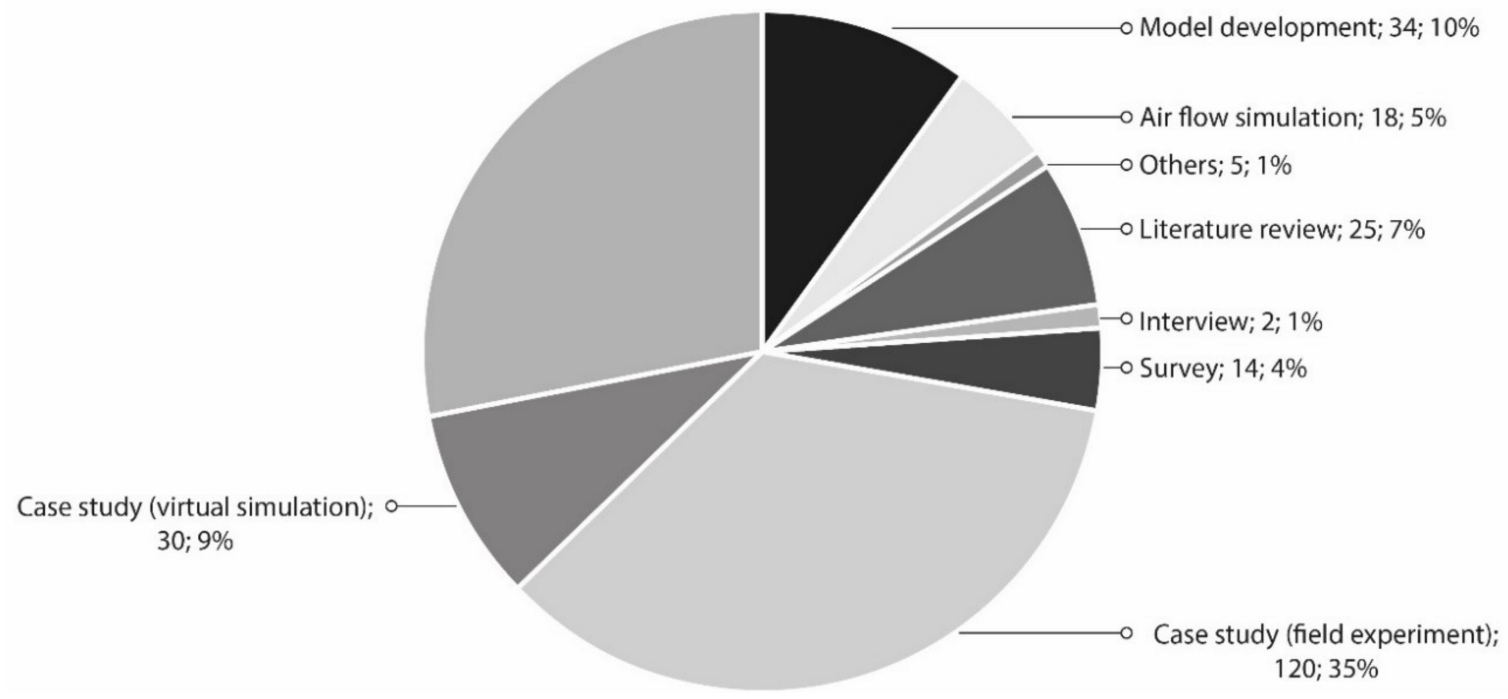

Figure 4. Overview of articles and applied research designs.

Many papers used field experiments in case studies to illustrate air pollution in cities or rural areas. In some studies, using case studies (field experiments), construction sites and construction activities, as well as their polluting influence on air, are the focus. Amongst others, De Moraes et al. have researched construction sites with a focus on air pollution in the context of concrete and masonry works [69]. Font et al. studied local air pollution at road construction works, which occurred as a result of road widening projects [88]. Giunta et al. also examined construction activities in a motorway construction project, and they identified the most significant air-polluting emissions during this process [89]. They also identified measures to reduce emissions and projected them for the future $[89,90]$. Moreover, air pollution (particulate matter) at bicycle lanes was researched by Thai et al., whereas it was shown that cycle roads were especially polluted next to construction sites with air pollutants (PM2.5 + PM10) [91]. Furthermore, Yan et al. also investigated the field of construction activities and dust pollution in China, showing that this topic has importance also in China [92]. In addition, indoor air quality was measured using case studies with field tests $[9,93]$.

Tang et al. evaluate building materials and their potential to reduce urban air pollution, specifically the $\mathrm{NOx}$ abatement capacity of $\mathrm{TiO}$-coated granules used in roofing products and there the method of use measurements [94]. Furthermore, measurements are applied as well, e.g., in the study Bossa et al. about Titanium dioxide nanomaterial within photocatalytic cement and its potential to reduce air pollution [95].

Air flow simulations are used e.g., by Bai et al., where ammonia in concrete walls is evaluated [96]. Moreover, Schripp et al. studied air flow simulations interaction of ozone (O3) and wooden building products as well as their emissions (e.g., volatile organic compounds or terpenes) [97].

The study of George et al. used a laboratory, field studies, and a smog chamber to test the potential of depollution of photocatalysis within construction materials and can be classified within the category different methods [98].

Surveys were applied, e.g., within a study that examined health problems of office clerks after relocation to a new office building [99]. The study found that the floor coating was the source of the air pollutant, with the consequence that it was removed afterward. Moreover, a survey was also conducted to investigate households in China and to compare regional differences in heating and air pollution in the different regions [100]. Also, Lindgren examined indoor air quality, specifically ammonia pollution in a new office building in Beijing [12]. Zhao et al. examined indoor air quality in residential buildings [79], and Sun et al. focused on the perception of public buildings by the occupants and users in the context of air quality using questionnaires [101]. 
Next to the building level and indoor air pollution, dust pollution control and mitigation measures were also researched with a survey [14], and also the indoor-outdoor association of NO2 was examined [102]. Moreover, Chiesa et al. examined PM and NOx reduction measures and policies in Italy using questionnaires [50]. Summing up, it can be said that in many papers indoor air quality and its consequences were studied using surveys. Furthermore, some scientific articles also addressed mitigation measures and policy with surveys or questionnaires, respectively. Literature reviews were also used in some of the articles. Cheriyan and Choi give a detailed overview of the construction industry and its particulate matter pollution using a literature review [10]. Tham reviewed the past 30 years of indoor air quality research and its and impacts on people [59]. Steinemann presented a literature review in the format of 10 questions and addressed green buildings and indoor air quality [56]. Mukherjee gives an overviewed of global PM sources and their occurrence and impacts on health in his literature review [53]. Furthermore, Fan gives a short literature review on silica exposure, its limits, and the most important guidelines as well as dust control measures connected to concrete drilling, the main topic of his article [103].

\subsection{Addressed Sub-Sectors and Building Types within the Construction Industry (RQ3)}

The results based on this RQ present a distribution of the investigated research articles to sub-sectors in construction sectors. In addition, the research articles are assigned to different building types and to the life cycle stages according to EN 15978 and EN $15084[71,72]$. In the process of the result analysis, the construction sector was divided into the sub-sectors buildings and infrastructure.

As shown in Figure 5, 6\% of the examined research articles are addressing the sector infrastructure, most articles (94\%) are referring to the sector building. In the sector building, residential buildings are addressed the most $(27 \%)$, followed by the category office buildings $(13 \%)$, educational buildings (11\%), and healthcare buildings (1\%). In 34\% of the research articles referring to buildings, no specific building type was mentioned. $14 \%$ of the research articles examined were assigned to the category Others. This category includes buildings such as shopping centers, factories, or cultural buildings such as museums or theatres.

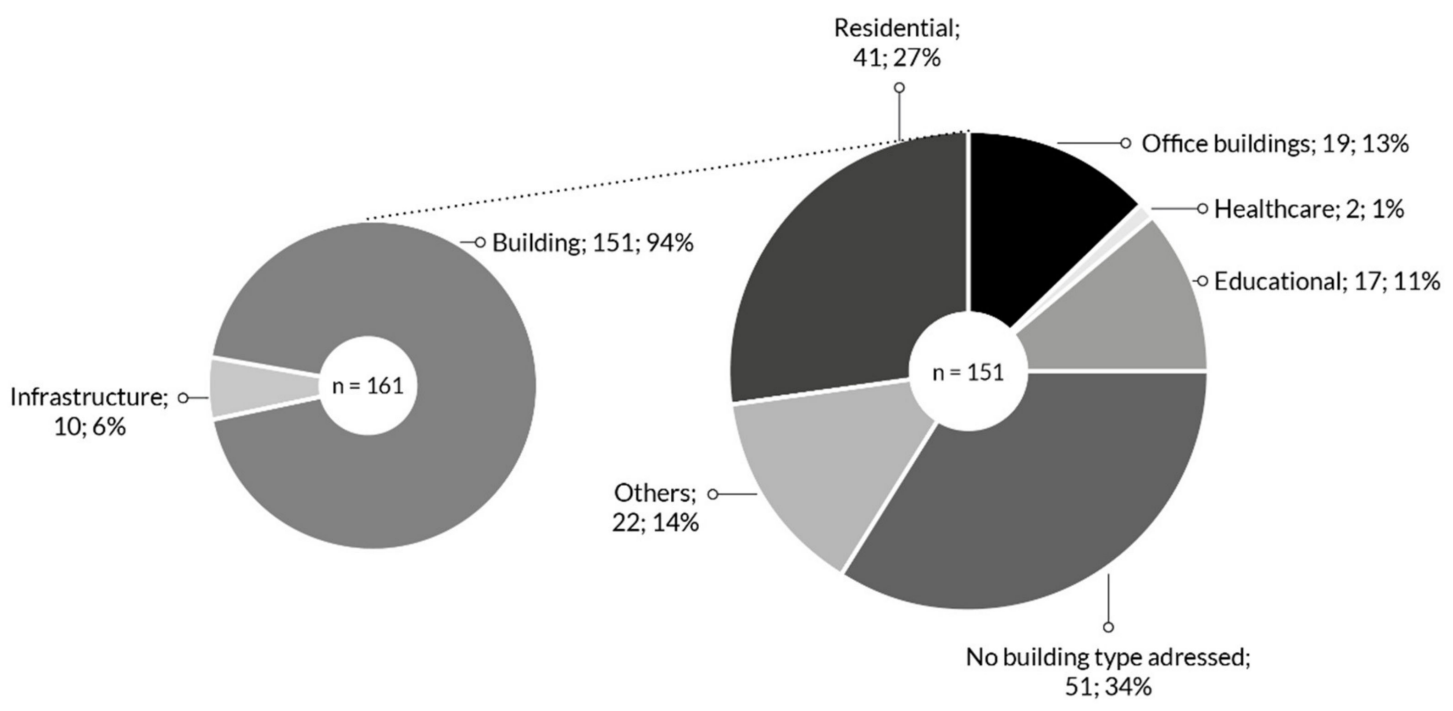

Figure 5. Addressed sub-sector and building types within the identified research articles.

Articles in the SLR which refer to infrastructure focused mainly on road construction works. For example, Faber et al. found that construction sites in Germany produce PM10 emissions and represent a high share (17\%) of the overall PM10 emissions of the country [104]. Font et al. examine air pollution from a road widening scheme during and after construction [82]. Fuller and Green examined road and construction works and 
addressed PM10 emissions, and Giunta and Giunta et al. refer to gas and dust emissions of road construction and road works or pavement materials and technologies for urban roads $[89,90,105]$.

Pollutants within residential and office buildings were examined in detail, as offices and residential buildings represent the two most important building types according to the SLR $[17,26,50,55,106,107]$. Within residential buildings, the most addressed pollutants are particulate matter (UFP, PM2.5, and PM10), followed by NO2 and NO2 as well as CO. For office buildings, PM2.5 is mentioned most often, followed by OC and $\mathrm{O} 3$ as well as NO2 and $\mathrm{CO}$ (see Figure 6).

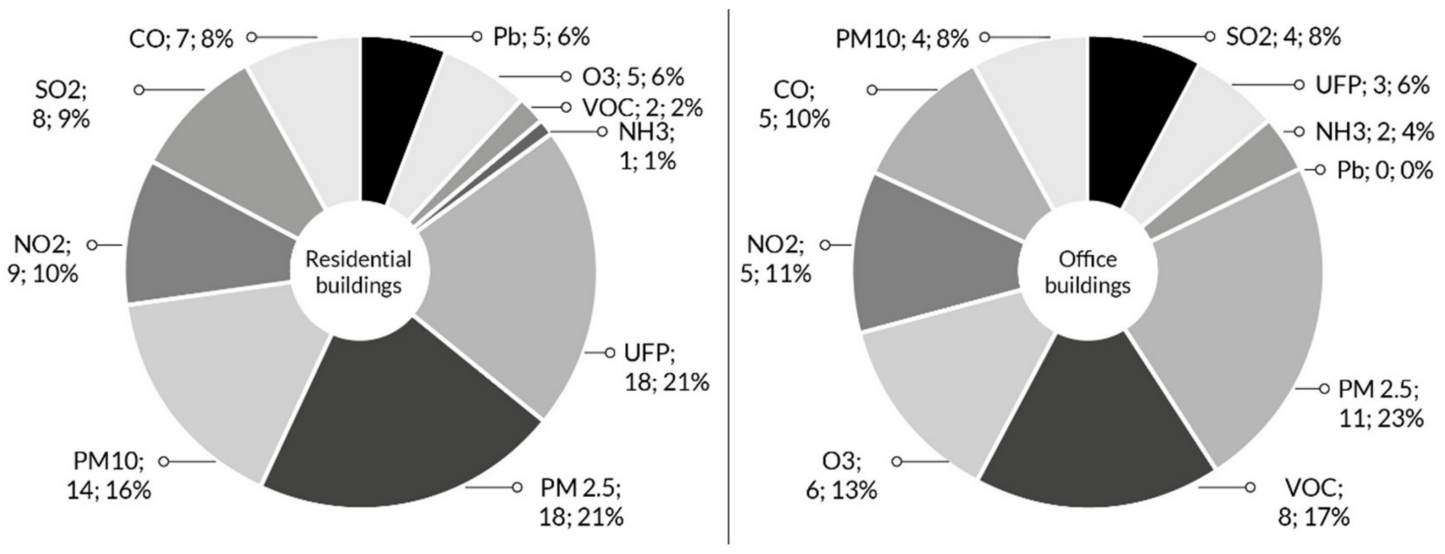

Figure 6. The most common pollutants in residential buildings and office buildings.

Healthcare buildings are addressed by Jing and Aung $[108,109]$. The study of Aung, a medical university, referred to as a healthcare building, is one of the sampling sites of Yangon, where air pollution measurements are conducted to close data gaps of indoor and outdoor air pollution [109]. In the study of Jing, the category hospital is among one of the five research building categories within the Chinese study, which offers supervision and an approach for evaluation of solid oxide fuel cell-based, combined cooling heating, and power demonstrations [108].

Educational buildings, which are largely schools, were the context for several different studies [57,64,65,110,111]. Moreover, Zanoletti's study was conducted at a university laboratory and proposes a new hybrid material for the sequestration of PM [82]. Additionally, Kozlovtseva's study refers to indoor air pollution with PM2.5 and PM10 in academic buildings at the Volgograd State University of Architecture and Civil Engineering in the Russian Federation [112].

Industrial construction was not addressed in detail, although one article by Bozkurt referring to air pollution in an industrial city in Turkey and Ekinci examined cement production and its implications for urban air pollution measures connected to growing urban air pollution with growing demand in the construction sector $[19,113]$.

\subsection{Construction Processes and Components}

A further detailed breakdown was made for construction sites and construction activities, construction equipment (including machinery), and building components.

Figure 7 shows how many research articles address construction sites and construction activities (49), construction machinery (7), and building components (157). Articles addressing building components are again divided into the four sub-categories (i) building envelope, (ii) building materials, (iii) interior, and (iv) heating, ventilation, and air conditioning (HVAC) systems. 


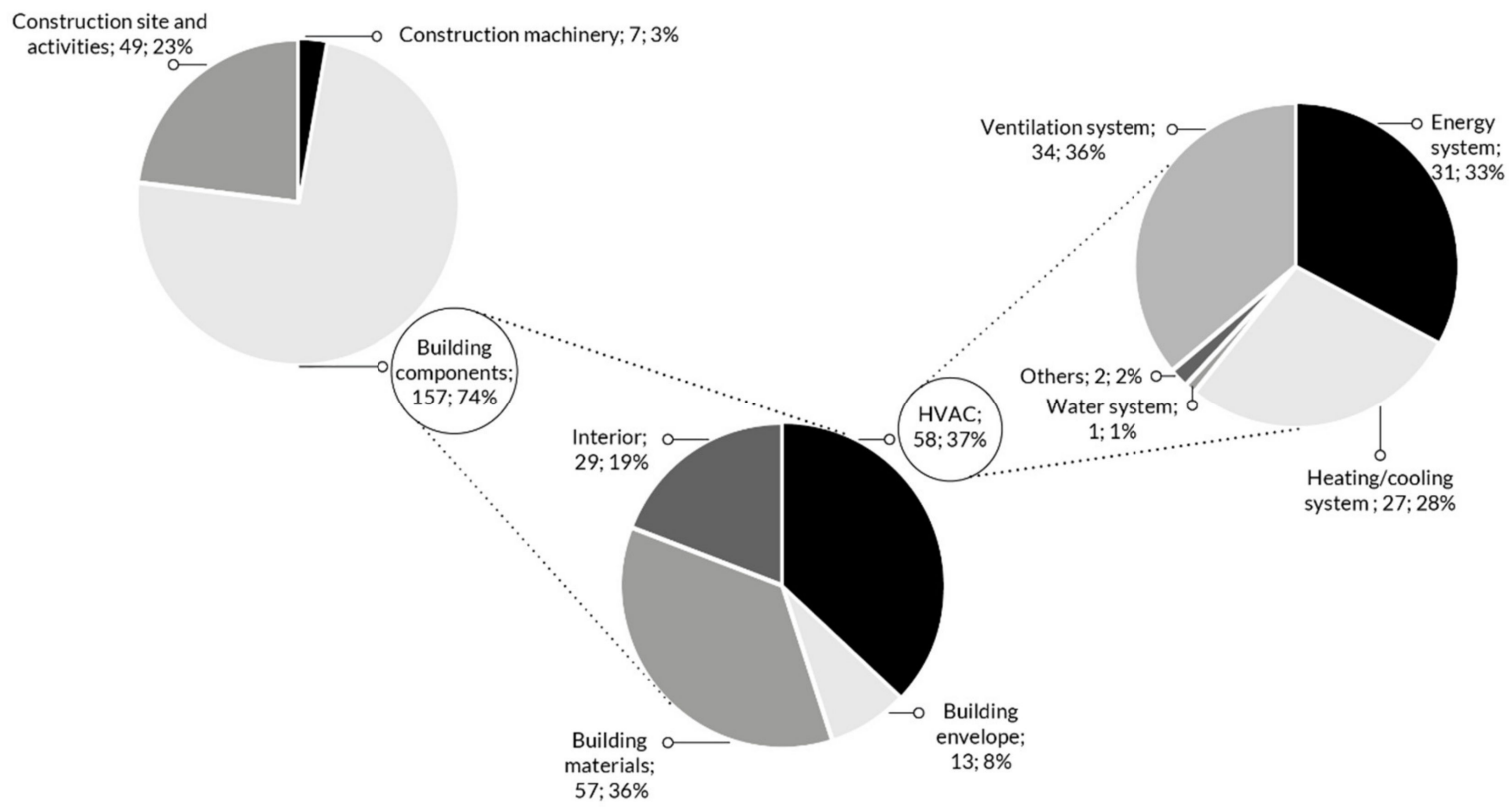

Figure 7. Overview of construction processes and (technical) components.

The results indicate that the building envelope is addressed 13 times, the building materials 57 times, the interior 29 times, and the HVAC systems 58 times in the research articles. The sub-category HVAC systems is again divided up into five more sub-fields, which are (i) ventilation system (34), (ii) energy system (31), (iii) heating/cooling system (27), (iv) water system (1), and (v) others (2).

Many studies of the final SLR sample are looking into construction sites and activities [14,114-116]. Alvanchi et al. are addressing construction management in their study and how improved construction schedules within infrastructure projects can improve the situation of urban air pollution [117]. Hassan et al. evaluated fugitive particulate matter emissions from construction sites in the Middle East, and Kinsey et al. examined fugitive dust and its relationship to mud or dirt discharge from a particular construction site in Kansas City [11,70]. Construction dust emission in a motorway project is the focus of Giunta et al. [89]. Faber et al. examined among other issues road construction in Germany and its emission effects on local air quality; one of the conclusions drawn from this study is that there are significant effects on air pollution [104]. Cheriyan and Choi reviewed $\mathrm{PM}$ in the construction industry and provided a summary of this issue in a literature overview [10]. Moreover, Liu et al. addressed construction activities in terms of construction as an economic sector. Their sector analysis shows that construction is the major source for $\mathrm{CO} 2, \mathrm{SO} 2, \mathrm{NOx}, \mathrm{PM} 2.5$, and BC emissions from a consumption perspective [118].

The following articles were referring to construction machinery $[10,21,92]$. The study of Faber et al. is looking into local air quality and aerosol emissions from construction sites, whereby the role of construction machinery is explicitly mentioned and researched in the study [104]. It shows that construction machinery is adding to air pollution, especially through organic particles and trace gases. The article of Giunta et al. studied emissions from construction activities for motorways. In this study, construction machinery was also a part of the overall emissive balance sheet. The study shows that trucks transit on unpaved or paved roads has the highest share of particulate emissions in the construction process [90]. Moreover, machinery and plant are responsible for $\mathrm{CO}$ pollution in construction activities. Heidari et al. conducted a cross-exanimation of the measured and the predicted emissions in their study. They found that significant discrepancies appeared between real-life data and the forecast emissions from different models [115]. 
In Figure 8, air pollutants in the context of the building envelope were examined. The results show that particulate matter (PM2.5-6 times, PM10-5 times) in various sizes is mainly addressed in the relevant articles focusing on the building envelope. Furthermore, also $\mathrm{NO} 2$ and $\mathrm{SO} 2$ emissions, as well as the category others, are each mentioned 4 times. Ozone (O3) is addressed 3 times, and the air pollutants UFP, CO, and VOC 2 times each.

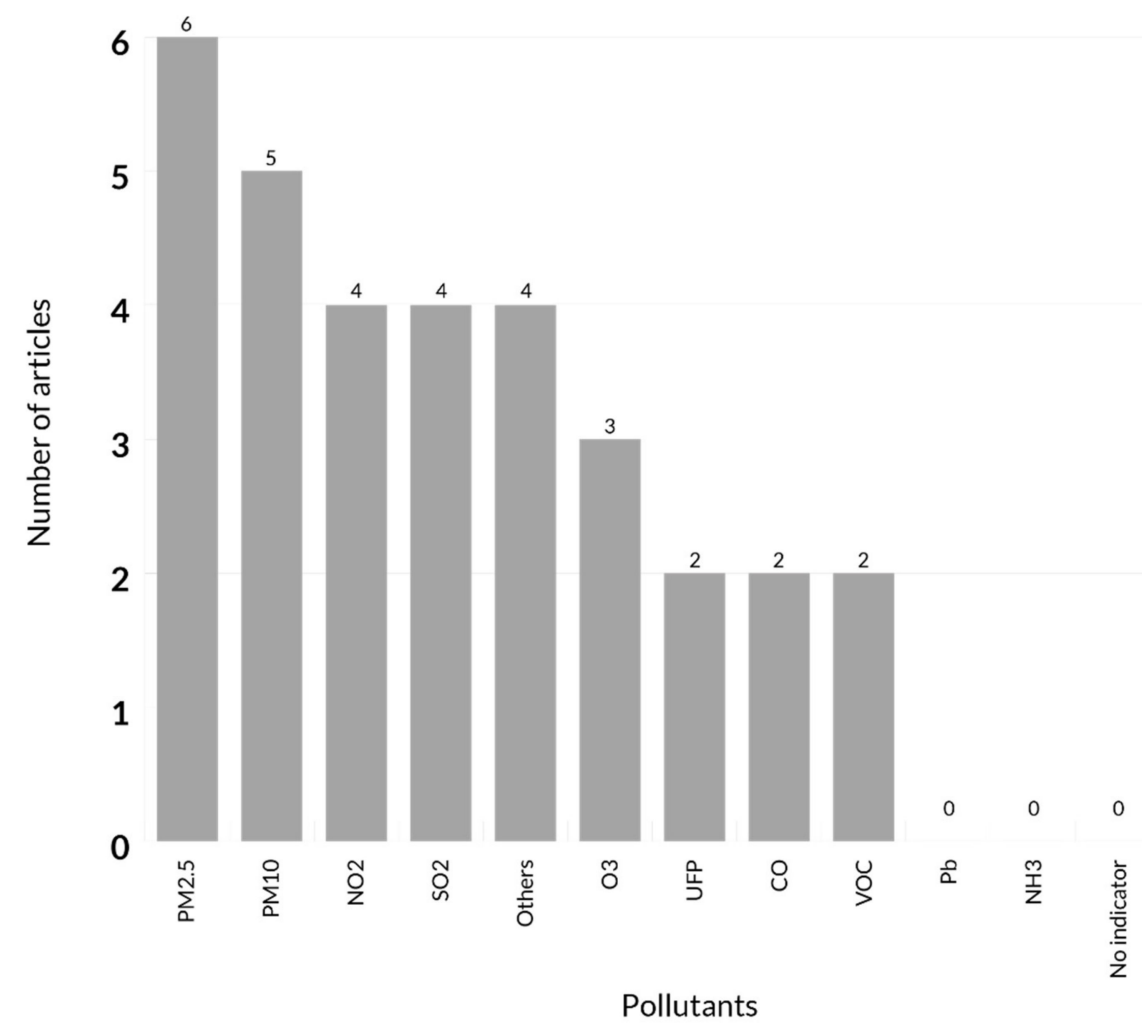

Figure 8. Overview of the pollutants mentioned in the building envelope context.

Building materials are addressed in 57 articles of the final sample. The pollutants most found in these articles were PM2.5 (84 times), PM10 (64 times), and VOC (57 times). Other pollutants such as $\mathrm{CO}$ (34 times), SO2 (32 times), and NO2 (31 times) also play a significant role. As shown in Figure 9, UFP and O3 are mentioned 26 times. Lead (Pb) and ammonia (NH3) are of less relevance and are each mentioned only 7 times.

Building interiors are referred to in 29 scientific articles. Figure 10 indicates that the most significant pollutant in these articles is VOC. VOC was mentioned in 26 out of 29 articles, suggesting a strong correlation between interiors and VOCs. The category Others is addressed 11 times, ozone 4 times, and PM2.5 3 times. UPF, PM10, and CO are addressed 2 times each. $\mathrm{NO} 2$ and $\mathrm{Pb}$ play an even less significant role, while $\mathrm{SO} 2$ and $\mathrm{NH} 3$ are not mentioned at all.

HVAC, as part of the studies reviewed, is mentioned, e.g., in the study of Che et al., who focused on a retrofitted HVAC system and its effects, and where in an office building, energy consumption and indoor air quality respectively environment are examined together [77]. Azuma et al. examined building-related symptoms and indoor air quality, which could affect human health in office buildings equipped with air conditioning in Japan. One result of the study was the finding that greater quantities of suspended particulate matter could enter the building via air conditioning systems in winter and that it is spread throughout the building with the indoor air. They suggest implementing filters for an improved air conditioning system and point out that correct maintenance is part of the solution for air pollution reduction [119]. 


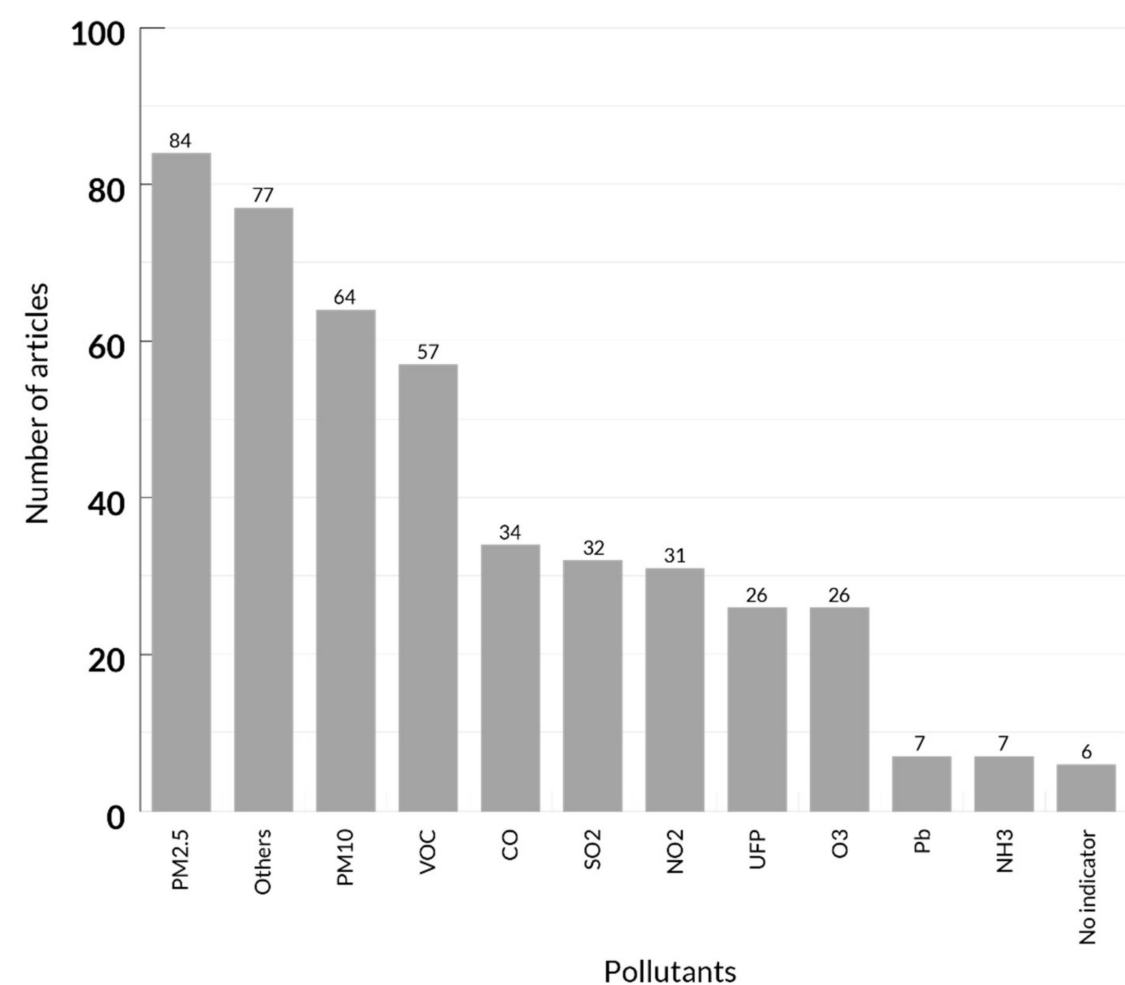

Figure 9. Overview of pollutants mentioned in the context of building materials.

30

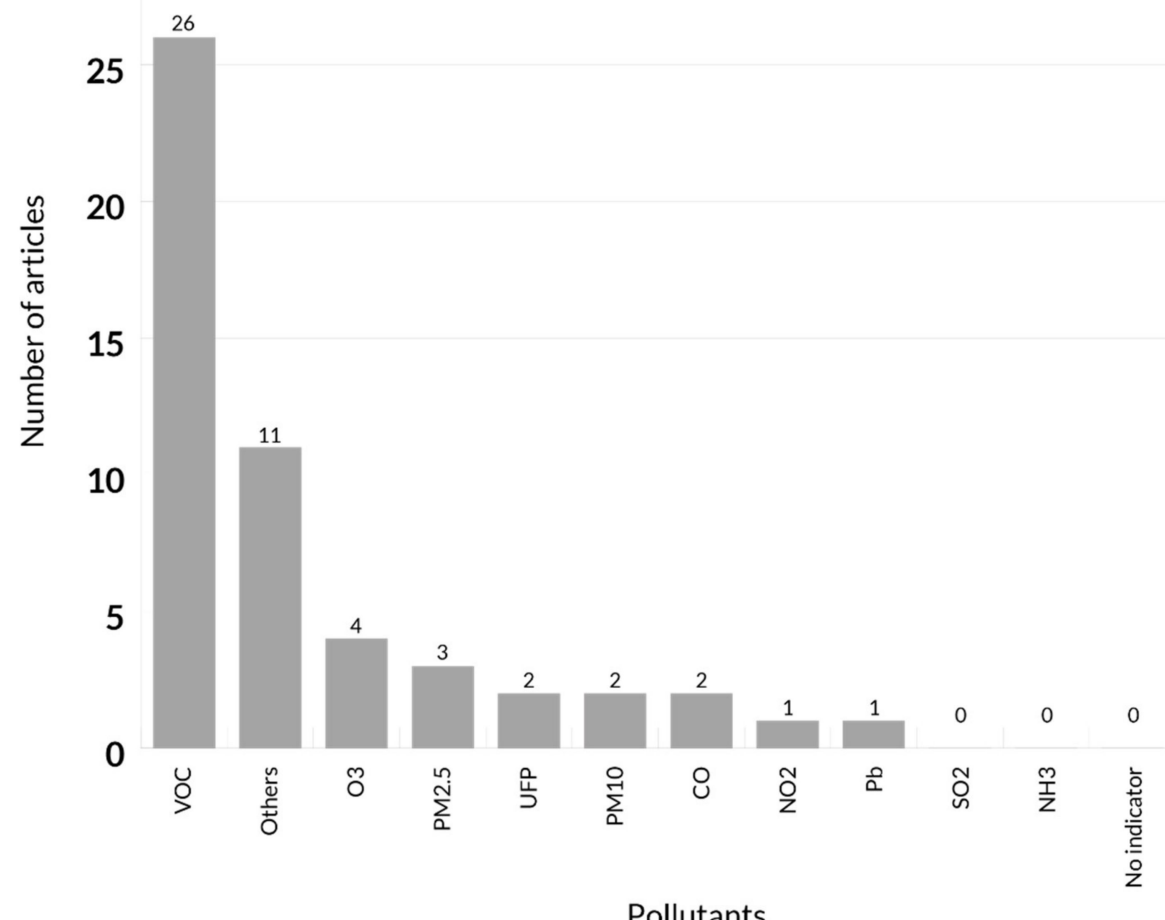

Figure 10. Overview of air emissions mentioned in the context of interiors.

Moreover, HVAC systems are targeted in the studies of Gabbe et al. and Asere et al. [106,120]. Moreover, Asere et al. are assessing indoor air quality in buildings in Latvia with an improved energy efficiency of the buildings. One of the results of the study is that ventilation systems and air exchange rates could be improved, which 
then on the other hand need more energy and contradict the original intention of energy efficiency measures [120]. Indoor air pollution is also caused by the interior and building materials with high emission potential [121]. For example, particle boards that are often used for furniture or floors are sources of formaldehyde and VOC emissions [122]. Additionally, decoration or interior elements such as floors or coatings can cause indoor air pollution $[79,99,123]$.

\subsection{Life Cycle Stages of Constructions}

A further result of this $R Q$ presents the assignment of the investigated research articles to the life cycle stages according to EN 15978 and EN 15084 [71,72].

The standard EN 15978 and EN 15084 classify the life cycle of construction works in the production stage (A1-A3), the construction stage (A4-A5), the use stage (B1-B7), the end-of-life stage (C1-C4) and benefits (D).

Figure 11 shows that by far the main life cycle stage addressed within the reviewed literature can be assigned to stage Use (module B1) with 73 mentions, followed by Operational energy use (module B6) with 31 mentions, and Construction-installation process (module A5) with 30 mentions. Life cycle modules Transport (module A4) and Manufacturing (module A3) are mentioned 23 times. Further important stages are Maintenance (module B2) and Refurbishment (module B5), as well as Raw material supply (module A1). All other life cycle modules are addressed 5 times or less.

80

70

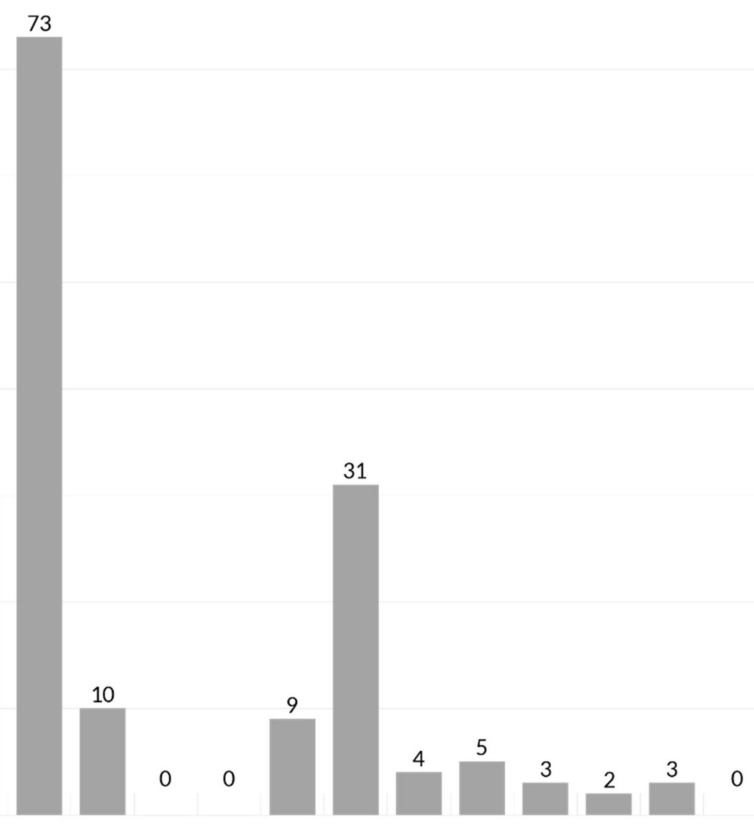

30

20

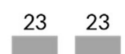

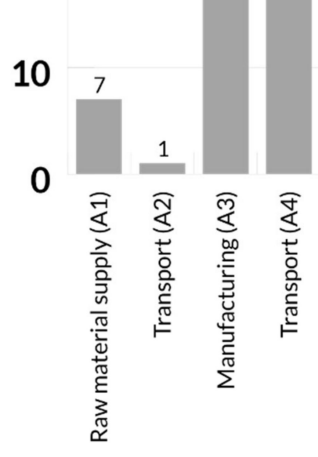

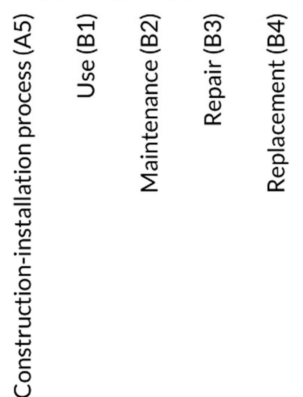

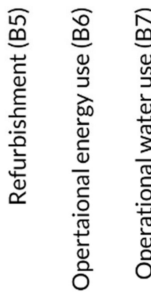

Life cycle stages

Figure 11. Addressed life cycle stages within the final sample. 
Transport is the most important air emission sector in Europe [6]. Transport occurs in different phases and modules during the lifecycle of a building [13,104,124]. It is part of the production stage (module A2) as transport of raw material to the manufacturing company, as well as part of the construction stage itself, e.g., for the transport to the constructioninstallation process/construction site (module A4). Moreover, it can also be part of the end-of-life stage of a building, i.e., as the transport needed for delivering the demolition or de-construction material to waste processing (module C2).

The production stage (module A1-A3) is part of the study of Asim et al., where catalyst geopolymers as a depolluting alternative to the concrete are studied and discussed [125]. Furthermore, Bossa et al. researched building materials, more specifically photocatalytic cement, as a possible pollution reduction option in the context of TiO2-nanomaterial release [95]. The study of Guttikunda et al. addressed air pollution and potential air pollution control measures for brick kilns with cleaner technology for brick production [126], among others. Böhm et al. are analyzing formaldehyde emissions from wooden products, i.e., solid wood, plywood, flooring, and block board [49]; the emissions were different for various products but highest in the first week after production for all.

The construction stage (module A4-A5) mainly refers to construction sites and construction work as well as the associated air pollution, especially particulate matter. In the course of the one-year study by Juda-Rezler et al., construction work is identified as one of the six main origins of everyday PM2.5 pollution in Poland [127]. Further to this, Ahmed and Arocho compare PM pollution (PM1.0, PM2.5, PM4.0, PM10) on two construction sites, one using steel and the other cross-laminated timber [128]. In addition, Guttikunda et al. are mentioning construction activities as important dust and particulate matter source (PM10 and PM2.5) within the city of Bengaluru [129].

The most widely addressed modules in the use stage (B1-B7) for the final SLR sample are B1 as the general use stage and B6 as the operational energy use stage.

Järnström et al. researched indoor air pollution concentrations, and measure VOC, ammonia, and formaldehyde concentrations during the first year of recently erected residential buildings [130]. Asere et al. have studied the effects of energy efficiency on air quality during the use stage of a building [120]. Du and Sun analyzed the correlation of regional characteristics of building heating systems and local air quality in China with different methods [100]. Among others, Guariso and Sangiorgio examine how the residential building stock should be renovated in terms of energy, looking to environmental and economic benefits and targets [131]. Additionally, local (air) pollution in the Italian region of Lombardia is addressed, as well as energy consumption and heating systems [125]. Dominikovic et al. are integrating and applying the aspect of air pollution in their optimization model for the planning of energy systems in tropical regions [126]. The study shows with its case study Singapore, that integration of energy systems helps to reduce air pollution and socio-economic costs of energy supply on the city level. Next to that, energy efficiency is identified as a part of the measures on the building level [48]. Additionally, Tunno et al. are looking into the topic of wood smoke during days and nights in Christchurch, New Zealand, which is, amongst others, a source for PM2.5 concentrations [132].

Besides that, Tong et al. are examining a tool, which helps to quantify impacts of retrofitting measures for buildings, which help to reduce the problem of air pollution in Ulaanbaatar in Mongolia [133]. Moreover, Shafique et al. investigate potential benefits of green roofing on air pollution reduction (in terms of $\mathrm{CO}_{2}$ ) and $\mathrm{CO}_{2}$-sequestration, and Karteris et al. are researching benefits for Greek large-scale green roof tops [134,135]. Next to air pollution by $\mathrm{CO}_{2}$, green roofs, respectively their plants, can absorb also other air pollutants such as ozone, PM10, or NO2.

Fuller et al. referred to the end-of-life phase (module C1-C4) in the context of air pollution (PM10 and PM2.5) by examining the demolition works for a chemical factory building and also a road case study in London [108]. Wu et al. also examined in their study about dust prevention and control, one construction site out of three in the stage of demolition [14]. 


\subsection{Distribution by Indoor and Outdoor Pollution (RQ4)}

Air pollution can be divided into indoor and outdoor pollution. In a pie chart, the proportions are shown and then analyzed in more detail.

Figure 12 presents which kind of air pollution is addressed in the analyzed research articles. Around half (51\%) of the articles are addressing outdoor pollution, almost a third $(31 \%)$ of the articles are addressing indoor pollution and a further $14 \%$ are addressing indoor and outdoor pollution.

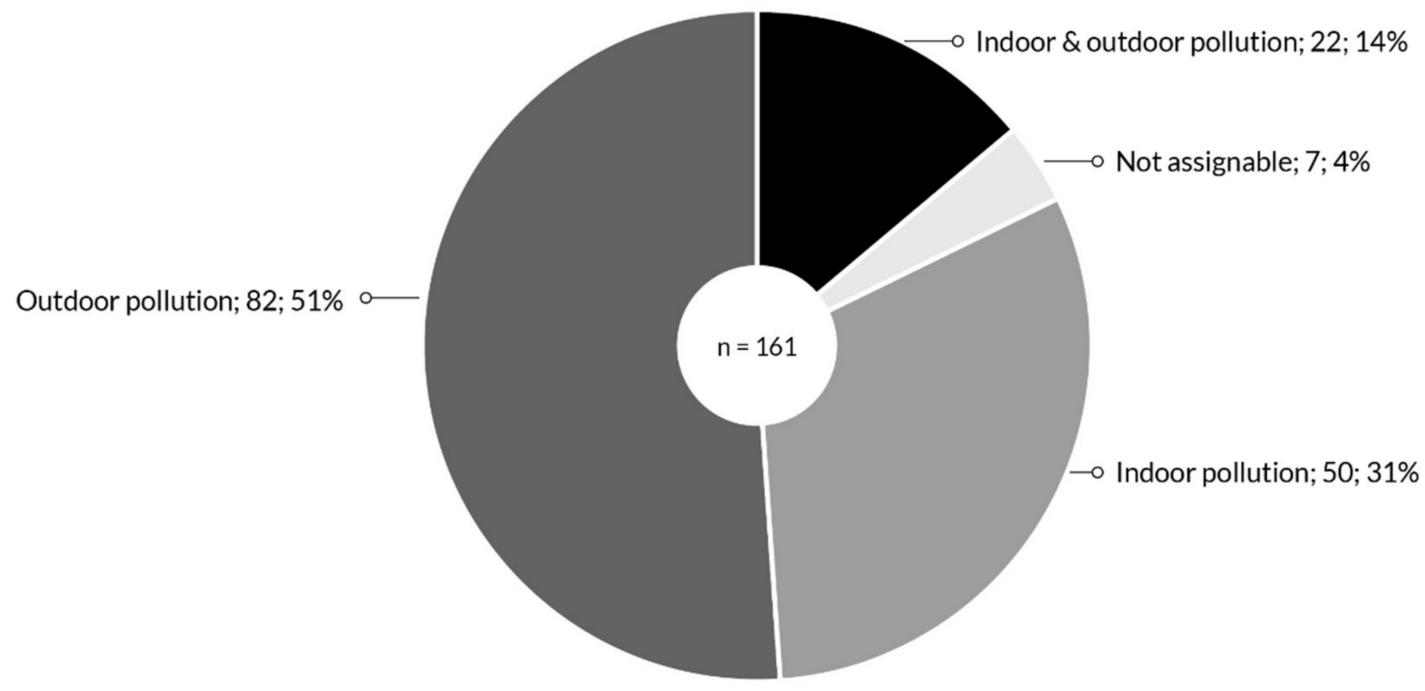

Figure 12. Classification of articles by indoor, outdoor, and indoor/outdoor pollution.

In several cases, indoor air quality (IAQ) measurements were conducted for different materials or building elements such as walls or different laboratory tests to better understand the functions and developments of indoor air pollutants [94-97,136].

Indoor or outdoor air pollutants were also researched in schools or cities such as the Yangon City in Myanmar [20,57,63,109,111]. As an example, PM2.5. concentrations in schools were researched in the studies of Amato et al. and Cancha et al. The use of materials and their effect on air pollution was measured within the study of Rella et al. $[65,66,113]$. Furthermore, the studies of Vervoort et al. focussed on a decrease of particulate matter in a school $[27,111]$. Wargocki and Wyon show in their study that the indoor (air) environment in schools matters because it can have a significant effect on the performance of school children [62]. Additionally, Yang et al. investigated the concentration of various air pollutants ( $\mathrm{CO}, \mathrm{CO}_{2}$, PM10, total microbial count, total volatile organic compound, formaldehyde) in Korean school buildings. It was shown that furnishings, building materials, and insufficient ventilation were all sources of bad indoor air quality. Moreover, indoor/outdoor ratios of air pollution were measured [20]. The study of Kim et al. focussed on indoor air pollution in the pre-occupancy stage of flats [93]. As a reduction measure for VOCs, the authors suggested better ventilation within the apartments, and the alternative could be decomposing agents.

Furthermore, office buildings and their indoor air quality were investigated in several studies. For example, Ruan and Rim examined two office building case studies in the US and in China [17]. They measured indoor O3 and PM2.5 concentrations in offices in Los Angeles and in Beijing and the effect of ventilation flow rates from the outside as well as the efficiency of filters. Hutter et al. investigated the health implication of office workers in a new office building. One of the findings was that tris-(2-butoxyethyl)-phosphate (TBEP) pollution developed mainly from floor coatings $(90 \%)$, which as a result were removed in order to reduce health issues connected with this material $[65,99]$. 


\subsection{Pollutants Analyzed in the Investigated Research Articles (RQ4)}

Air pollutants addressed in the research articles are shown in a pie chart in Figure 13 below. The population of investigated research articles $(n=451)$ exceeds the number of identified research articles $(n=161)$ due to multiple answers.

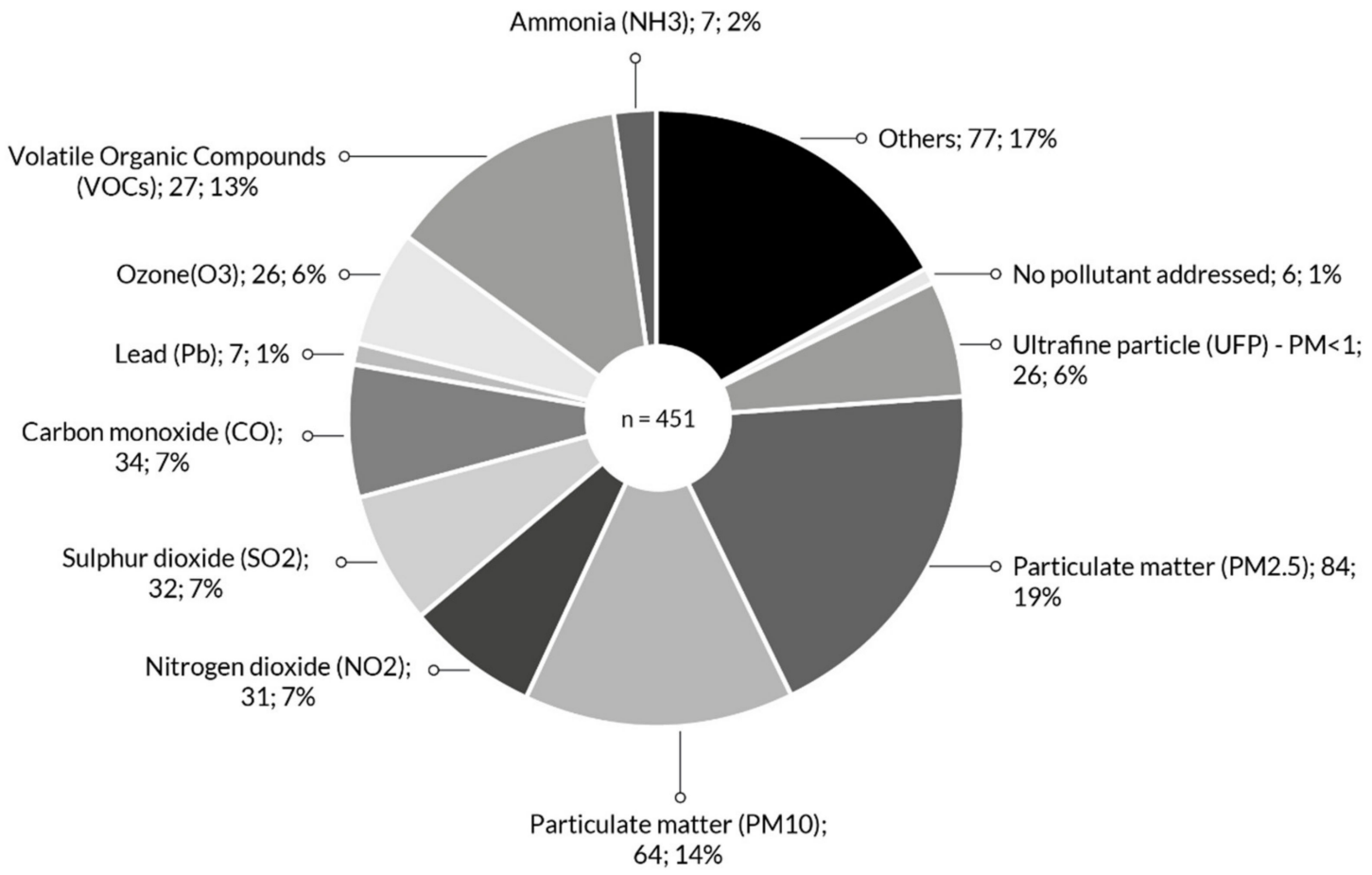

Figure 13. Overview of addressed air pollutants within the final SLR sample.

Particulate matter (PM) in different sizes can be identified in most of the air pollutants in the examined research articles. Particulate matter (PM2.5) represents a share of $19 \%$, Particulate matter (PM10) 14\%, and Ultrafine particle (UFP), which is PM $<1$, constitute $6 \%$ of the population. With $17 \%$, the category of Others is the second biggest category after PM2.5, which comprises of, e.g., black carbon, NOx, and SOx. The third-largest group is represented by Volatile Organic Compounds (VOCs). With 7\%, Sulphur dioxide (SO2), Nitrogen dioxide (NO2), and Carbon monoxide (CO) are addressed with equal frequency. Ozone (O3) with $6 \%$ is mentioned as often as UFP. Ammonia (NH3) is only examined in 7 research articles, which represents a $2 \%$ share of the analyzed research articles. Lead $(\mathrm{Pb})$ represents $2 \%$ of the overall research articles and is covered in 7 research articles. In 1\% (6 research articles), No pollutant is addressed explicitly

$\mathrm{PM}$ of different sizes in construction sites was addressed in the article of Ahmed and Arocho, which provides clear confirmation that construction sites emit PM in different sizes (PM1.0, PM2.5, PM4, PM10) [128]. Saliba et al. investigated PM and its composition at urban sites in Beirut [137]. The study found that construction debris is also a source of pollution with fine PM. In the study of Azuma et al., air quality and effects on the health (building-related symptoms) of office workers in offices were examined, whereby UFP, in particular, had an effect on building-related symptoms, and VOCs or toluene were linked with health effects on upper respiratory symptoms [119].

In the study of Liu et al., a structural path analysis was conducted, the authors looked at the embodied emission of supply chains such as NOx or SO2, where on the consumption side, construction contributed a larger share to this emission (20-38\%) [118]. The construction sector and building materials were among the leading areas regarding important emissions $[90,118]$. 


\section{Discussion}

The aim of the study was to gain a comprehensive overview of how the construction industry contributes to air pollution, where air pollution occurs, and what topic-related research has been conducted in the various fields of the construction industry-in all its aspects.

Three main areas were analyzed with the final sample of the SLR. Firstly, the building level and its life cycle stages, secondly, the construction processes and elements (e.g., construction sites and building components), and thirdly, construction materials and the interiors of buildings. Only one review article of the SLR provides a review of PM air pollution in the explicit context of the construction industry. PM is a prime focus of this article with particular emphasis on the health impacts due to PM exposure for construction workers. The second focus of this study was put on construction dust and especially the monitoring of construction dust from construction activities [10].

Therefore, the first step was to identify important journals and research fields (RQ1). Their variety shows the multi- and interdisciplinarity of the research topic (air pollution in the construction industry), which is rooted in building science, air pollution research, and environmental research. It is in the nature of that topic that no one single research method or methodology can be used to cover this diverse field. Therefore, the articles conveyed a variety of methods and research designs (RQ2) from different disciplines and journals. Another trend observed was that the number of publications in the field of construction is rising (RQ1). In geographical terms, most of these papers are published by Chinese universities. The intense research on air pollution is most probably a reflection of the attempt that is being made to tackle the huge air pollution problem in China. Chinese publications are followed by publications originating from the United States.

One research interest of the SLR study was to identify types, activities, and stages of the built environment or buildings in the current literature (RQ3). The research articles were assigned to different building types and life cycle modules according to EN 15978 and EN15804. The analysis showed that most of the reviewed articles addressed buildings ( $94 \%$ of articles) and that only a small percentage addressed infrastructure (6\%). Residential buildings, office buildings, and educational buildings are the most intensively represented of the building types addressed. Additionally, construction processes and construction components were addressed. A classification was thus made in the analysis according to construction component types. Many of the research articles addressed building components (157), construction sites and activities (49), or construction machinery (7). In detail the components were divided into four sub-categories: (i) building envelope, (ii) building materials, (iii) interior, and (iv) heating, ventilation, and air conditioning (HVAC) systems.

Particulate matter (PM) in various sizes is among the most frequently addressed air pollutant in the final sample with $17 \%$, the category Other (this category includes, e.g., black carbon or NOx and Sox) being the second largest category after PM2.5. As the third-largest group, Volatile Organic Compounds (VOCs) can be identified. Air pollutants can be found indoors, outdoors, and in both. Moreover, indoor pollution articles comprised almost a third of the final sample and in this light, could be regarded as an independent (sub) research field. Building materials and interiors both play important roles in this area.

Moreover, one of the implicit set questions is how to improve the situation of air pollution reduction in the construction industry and furthermore to include air pollution reduction measures for fulfilling international agreements and policies such as the Agenda 2030, in order to contribute to sustainable development and transformation of the construction industry.

In the SLR, the scientific articles were also screened for their connection with different sustainable development goals (SDGs). Measures for cleaner and better air in the construction industry can be set either on a technical and operational level or on a policy level. The Agenda 2030 can provide a framework for policy instruments and measures for transforming the construction industry in the interest of a more sustainable and healthier built environment. As the SDGs are interrelated and there are systemic interactions among 
the SDGs in the construction industry $[138,139]$, some SDGs and their targets refer to air pollution. The topic of health is addressed in SDG target 3.9. and is also reflected in the articles, e.g., through the sick building syndrome or the topic of well-being in buildings, in schools and offices among others, and in the research field of indoor air pollution and indoor air quality. Sustainable urbanization and air pollution are addressed in SDG target 11.6 with UN indicator 11.6.2., which for example, includes only PM (e.g., PM2.5 and PM10) in cities but does not address other relevant air pollutants such as $\mathrm{NOx}, \mathrm{O} 3, \mathrm{~Pb}$, or $\mathrm{SO}$, although they are relevant air pollutants, as outlined in the Section 3. This emphasizes the need for tackling the challenge of air pollution in the construction industry especially in cities and urban areas.

As with other sustainability aspects that need to be taken into account at an early stage in the construction industry, a holistic and systemic view of the influencing criteria is also required in connection with the reduction of air pollution, as well as awareness-raising among the stakeholders involved $[140,141]$. On a technical and operational level, various measures within the entire life cycle of a building or even an infrastructure contribute to ensuring cleaner air and to both healthier people and a healthier planet. Measures for achieving these goals could be e.g., a reduction of transport activities together with a better management of construction sites or construction schedules in a city in order to optimize distances and avoid traffic jams, which can contribute to higher emissions. Further measures include shortening the distances for the transport of building material by using local enterprises and services and using regional building materials. Technical measures and improvements such as the humidification of tires on construction sites to prevent dust emissions or the optimization of construction site equipment to protect residents and neighbors from dust and noise can be helpful. One possible measure at the legal and administrative levels is the increased integration of dust and air pollution control measures into official tendering and awarding procedures, e.g., the use of hybrid or electrical construction machinery. Measures can be implemented by different actors such as construction companies or owners of buildings on the level of cities and communities or even on policy level on a national or international scale. The international and national guidelines should be implemented at the regional level by local government or at the individual level, e.g., by building owners and construction companies.

In addition, the cooperation of stakeholders from science to industry can also be helpful for the creation of knowledge and the implementation of cleaner air measures. In this context, the Austrian UniNEtZ project can be pointed out, in which a total of 17 universities co-operate in order to implement the SDGs in Austria [142]. One goal of the project is to propose an options paper to the Austrian government as a recommendation for the implementation of various measures to achieve the Agenda 2030 goals.

In this context, all of the 161 screened articles contribute directly or indirectly to sustainable development. However, none of the articles explicitly mentioned the SDGs. The results of the SLR show that air pollution is receiving increasing attention in the scientific community. This is probably due to its environmental, economic, and social implications. Nevertheless, the number of comprehensive reviews on air pollution in the construction industry could be increased, for example by examining certain specific aspects or subtopics such as specific pollutants in different life cycle stages or the linkage of air pollution reduction measures in general or in combination with greenhouse gas (GHG) emission reduction measures and emphasizing synergies between these two topics. Several SLR articles mentioned GHG emissions in the construction industry context $[56,63,141]$. The relationship between air pollutants and GHG emissions, however, is not quantified in the SLR papers reviewed. It is striking, however, that the connection between GHG emission (i.e., $\mathrm{CO}_{2}$-eq.) and air pollution is not addressed.

Finally, it can be shown that in both the SLR articles and in policy, e.g., the Agenda 2030 and its SDG targets, a special emphasis on PM can be identified. Other problematic emissions and air pollutants, which are also heavily burdening the environment, are underexposed in scientific literature. 
In this context, the question is whether this is because PM is the most harmful air pollutant in construction, or because it is one of the easiest to measure and research. An allocation of air pollution to the construction industry is difficult due to the overlapping system boundaries. Air pollution itself does not consider the construction industry as a separate sector but is interwoven in different sectors such as transport, industry, or energy. It is apparent from the SLR that the formulated RQs are not yet being addressed with great frequency in specific academic fields and universities, or in specific geographical areas such as African or South American countries.

\section{Limitations}

A thematic limitation of the study and the conducted SLR is that it focuses mainly on buildings and infrastructure. Literature focusing on other topics such as urban forms, urban planning, the urban built environment in general, and urban greenery such as green walls, green roofs or trees, was excluded. Moreover, the effect air pollution has on buildings, building materials, and the built environment is not yet being addressed. Further articles focusing on cooking, which also contributes to air pollution, were not part of this literature review. Additional constraints are shown in Figure 1.

\section{Conclusions and Future Perspectives}

This article is the first comprehensive overview of the literature specifically on air pollution in the construction industry and its various aspects. It can be concluded that air pollution is a relevant environmental issue in the construction industry and in the whole construction process.

The research field of air pollution related to the construction industry still has a lot of potentials, because, mostly, only single topics or aspects of "air pollution" and "construction industry" are treated and investigated in individual articles. According to the SLR, the number of articles on air pollution in the construction industry has been rising in the last few years. That the combination of both research issues is a broad field can also be seen in the variety of the journals addressed. There is not just one overall method or methodology set to explore this interdisciplinary research area, even if case studies with field experiments and measurements/method development are most often used in the studies of the final SLR sample. Residential, office, and educational buildings stand out the most in the category of building types and particulate matter in different sizes represents the most common pollutant within the SLR. In addition, one of the results is that both outdoor and indoor air pollution can be considered important for air pollution, the construction industry, and a healthy living environment.

The implementation of a systemic view (i.e., the consideration of a set of sustainable development performance indicators in assessing the appropriateness of air pollutant reduction measures) involves a crucial increase in complexity. The current (scientific) lack of reliable data, the choice of meaningful system boundaries, and the current prevailing reductive thinking approaches of air pollution reduction strategies in the construction sector are the chief limiting factors from the authors' point of view.

According to the Austrian Federal Environment Agency, the sectors of industry (34\%), small-scale consumption (21\%), agriculture (20\%), and transport (18\%) are responsible for the generation of particulate matter. In the small-scale consumption sector, combustion processes (stoves, heaters) and in the transport sector, the operation of engines (mainly diesel engines), through brake and tire abrasion as well as dust whirling up on the road are responsible for the emissions. From the point of view of the construction industry, emissions from domestic heating (due to old solid fuel heating systems) and construction sites are particularly relevant.

However, the distinction between the sectors industry and transport, which should be partially within the system boundary of the construction industry, is unclear. Another obstacle is the insufficient understanding regarding the relocation of "dirty" technologies to countries that already are struggling with their bad air quality conditions. 
There are different areas, where measures and activities can be taken to reduce air pollution within the various stages of a life cycle of a building. Building materials also influence clean air, especially inside a building. In this way, taking measures against air pollution and for cleanliness, a decrease of premature mortality and different diseases can be achieved. With the right measures and policies, (co-) benefits and synergies between health, climate, air quality, and the environment can be used, and, in this way, the building occupants can also profit. Appropriate actions can achieve and contribute to various policy agendas such as the SDGs and their targets. This will require better planning and management of construction projects and buildings by taking their life cycles and the built environment into consideration. In addition to this, improved materials that are both reusable and recyclable, together with thoroughly adequate technologies and approaches will help us to generate a reduced environmental impact.

Possible ways to give an overview about environmental impacts or to reduce the impact on the environment are methods such as life cycle assessment (LCA), which can be integrated as a decision tool in the construction planning process at an early stage. Green and sustainable public procurements policies, which consider social and environmental criteria and make every effort to avoid negative social and environmental impacts should be considered and implemented from the beginning of the life cycle.

Furthermore, it is important to integrate findings from different disciplines to provide a holistic view of sustainable construction practices and construction materials for clean air and to avoid air pollution in the future. To these terms, the construction industry can contribute cleaner building practices and help to achieve cleaner air.

In this context, the key remaining question will be how to create a systemic understanding of air pollution effects (induced by the construction sector) across all 17 SDGs. Therefore, and as a basis, the consideration of transdisciplinary effects within the policymaking process is of particular importance in order to raise awareness between various sectors and stakeholders.

Author Contributions: Conceptualization, A.A.W., M.S. and H.K.; methodology, A.A.W. and M.S.; validation, M.S. and H.K.; formal analysis, A.A.W. and M.S.; investigation, A.A.W. and M.S.; resources, A.A.W. and M.S.; data curation, A.A.W. and M.S.; writing-original draft preparation, A.A.W. and M.S.; writing—review and editing, M.S. and H.K.; visualization, A.A.W. and M.S.; supervision, A.P. and H.K.; project administration, H.K. All authors have read and agreed to the published version of the manuscript.

Funding: Supported by TU Graz Open Access Publishing Fund.

Institutional Review Board Statement: Not applicable.

Informed Consent Statement: Not applicable.

Data Availability Statement: All data used are available in the article or in the references.

Acknowledgments: This article was created in the framework of the research project UniNEtZUniversities and Sustainable Development Goals initiated by the Alliance of Sustainable Universities in Austria. Special thanks to the great cooperation with all of the universities involved in UniNEtZ and to the Austrian Federal Ministry of Education, Science and Research (BMBWF) for supporting the project.

Conflicts of Interest: The authors declare no conflict of interest.

\section{References}

1. WHO. Air quality and Health. In Fact Sheets on Sustainable Development Goals: Health Targets; World Health Organization Region Office for Europe: Copenhagen, Denmark, 2018.

2. EPA. Criteria Air Pollutants. Available online: https:/ / www.epa.gov/criteria-air-pollutants\#sel (accessed on 9 June 2021).

3. WHO. World Health Statistics 2020: Monitoring Health for the SDGs, Sustainable Development Goals; WHO: Geneva, Switzerland, 2020.

4. WHO. Ambient Air Pollution. Available online: https://www.who.int/data/gho/data/themes/topics/topic-details/GHO/ ambient-air-pollution (accessed on 9 June 2021). 
5. WHO. Public Health Social and Environmental Determinants of Health Department Burden of Disease from the Joint Effects of Household and Ambient Air Pollution for 2016; WHO: Geneva, Switzerland, 2018.

6. European Environment Agency (EEA). Air Quality in Europe-2020 Report; European Environment Agency (EEA): Copenhagen, Denmark, 2020; ISBN 978-92-9480-292-7.

7. European Commission. Impact Assessment on Air Pollution in Europe: An Executive Summary; European Commission Working Document; European Commission: Brussels, Belgium, 2013.

8. Xu, P.; Chen, Y.; Ye, X. Haze, air pollution, and health in China. Lancet 2013, 382, 2067. [CrossRef]

9. Bourdin, D.; Mocho, P.; Desauziers, V.; Plaisance, H. Formaldehyde emission behavior of building materials: On-site measurements and modeling approach to predict indoor air pollution. J. Hazard. Mater. 2014, 280, 164-173. [CrossRef]

10. Cheriyan, D.; Choi, J. A review of research on particulate matter pollution in the construction industry. J. Clean. Prod. 2020, 254, 120077. [CrossRef]

11. Kinsey, J.; Linna, K.; Squier, W.; Muleski, G.; Cowherd, C. Characterization of the Fugitive Particulate Emissions from Construction Mud/Dirt Carryout. J. Air Waste Manag. Assoc. 2004, 54, 1394-1404. [CrossRef] [PubMed]

12. Lindgren, T. A case of indoor air pollution of ammonia emitted from concrete in a newly built office in Beijing. Build. Environ. 2010, 45, 596-600. [CrossRef]

13. Muleski, G.; Cowherd, C.; Kinsey, J. Particulate Emissions from Construction Activities. J. Air Waste Manag. Assoc. 2005, 55, 772-783. [CrossRef]

14. Wu, Z.; Zhang, X.; Wu, M. Mitigating construction dust pollution: State of the art and the way forward. J. Clean. Prod. 2016, 112, 1658-1666. [CrossRef]

15. Yang, S.; Liu, J.; Bi, X.; Ning, Y.; Qiao, S.; Yu, Q.; Zhang, J. Risks related to heavy metal pollution in urban construction dust fall of fast-developing Chinese cities. Ecotoxicol. Environ. Saf. 2020, 197, 110628. [CrossRef] [PubMed]

16. Challoner, A.; Gill, L. Indoor/outdoor air pollution relationships in ten commercial buildings: $\mathrm{PM}_{2.5}$ and $\mathrm{NO}_{2}$. Build. Environ. 2014, 80, 159-173. [CrossRef]

17. Ruan, T.; Rim, D. Indoor air pollution in office buildings in mega-cities: Effects of filtration efficiency and outdoor air ventilation rates. Sustain. Cities Soc. 2019, 49, 101609. [CrossRef]

18. Bogush, A.A.; Stegemann, J.A.; Zhou, Q.; Wang, Z.; Zhang, B.; Zhang, T.; Zhang, W.; Wei, J. Co-processing of raw and washed air pollution control residues from energy-from-waste facilities in the cement kiln. J. Clean. Prod. 2020, 254, 119924. [CrossRef]

19. Ekinci, E.; Kazancoglu, Y.; Mangla, S.K. Using system dynamics to assess the environmental management of cement industry in streaming data context. Sci. Total Environ. 2020, 715, 136948. [CrossRef]

20. Yang, W.; Sohn, J.; Kim, J.; Son, B.; Park, J. Indoor air quality investigation according to age of the school buildings in Korea. J. Environ. Manag. 2009, 90, 348-354. [CrossRef]

21. Zhang, X.; Shen, L.; Zhang, L. Life cycle assessment of the air emissions during building construction process: A case study in Hong Kong. Renew. Sustain. Energy Rev. 2013, 17, 160-169. [CrossRef]

22. Berghmans, P.; Bleux, N.; Panis, L.I.; Mishra, V.K.; Torfs, R.; Van Poppel, M. Exposure assessment of a cyclist to PM $_{10}$ and ultrafine particles. Sci. Total Environ. 2009, 407, 1286-1298. [CrossRef] [PubMed]

23. Shao, Z.; Bi, J.; Ma, Z.; Wang, J. Seasonal trends of indoor fine particulate matter and its determinants in urban residences in Nanjing, China. Build. Environ. 2017, 125, 319-325. [CrossRef]

24. Bencs, L.; Spolnik, Z.; Worobiec, A.; Samek, L.; Jütte, B.A.H.G.; Van Grieken, R. Effects of IR heating on distribution and transport of gaseous air pollutants in urban and mountain churches in Poland. J. Cult. Herit. 2019, 36, 200-209. [CrossRef]

25. Jaber, J.O. Prospects of energy savings in residential space heating. Energy Build. 2002, 34, 311-319. [CrossRef]

26. Quang, T.N.; He, C.; Morawska, L.; Knibbs, L.D. Influence of ventilation and filtration on indoor particle concentrations in urban office buildings. Atmos. Environ. 2013, 79, 41-52. [CrossRef]

27. Page, M.J.; McKenzie, J.E.; Bossuyt, P.M.; Boutron, I.; Hoffmann, T.C.; Mulrow, C.D.; Shamseer, L.; Tetzlaff, J.M.; Akl, E.A.; Brennan, S.E.; et al. The PRISMA 2020 statement: An updated guideline for reporting systematic reviews. J. Clin. Epidemiol. 2021, 134, 178-189. [CrossRef]

28. Higgins, J.; Green, S. Cochrane Handbook for Systematic Reviews of Interventions; Cochrane Book Series; The Cochrane Collaboration: London, UK, 2008; ISBN 978-0-470-69951-5.

29. Wholin, C. Guidelines for Snowballing in Systematic Literature Studies and a Replication in Software Engineering. In Proceedings of the 18th International Conference on Evaluation and Assessment in Software Engineering, London, UK, 13-14 May 2014.

30. Richie, H.; Roser, M. Air Pollution. Available online: https:/ / ourworldindata.org/air-pollution (accessed on 9 June 2021).

31. Apte, J.S.; Brauer, M.; Cohen, A.J.; Ezzati, M.; Pope, C.A. Ambient PM 2.5 Reduces Global and Regional Life Expectancy. Environ. Sci. Technol. Lett. 2018, 5, 546-551. [CrossRef]

32. Health Effects Institute. State of Global Air 2019. Special Report; Health Effects Institute: Boston, MA, USA, 2019. Available online: https:/ / www.stateofglobalair.org/sites/default/files/soga_2019_report.pdf (accessed on 9 June 2021).

33. WHO. Policy and Progress-Ambient Air Pollution. Available online: https://www.who.int/teams/environment-climatechange-and-health/air-quality-and-health/ambient-air-pollution/policy-and-progress (accessed on 9 June 2021).

34. UNEP. Stockholm Convention on Persiten Organic Pollutants (POPS)—Text and Annexes_Revised in 2019; UNEP: Geneva, Switzerland, 2020; p. 79. 
35. European Commission Clean Air Programme. Available online: https://ec.europa.eu/environment/air/clean_air/index.htm (accessed on 21 June 2011).

36. European Parliament and Council. Directive 2008/50/EC of the European Parliament and of the Council of 21 May 2008 on Ambient Air Quality and Cleaner Air for Europe; European Parliament and Council: Strasbourg, France, 2008.

37. European Commission Air Quality-Existing Legislation. Available online: https://ec.europa.eu/environment/air/quality/ existing_leg.htm (accessed on 11 June 2021).

38. United Nations. Resolution A/RES/70/1-Transforming Our World: The 2030 Agenda for Sustainable Development; United Nations: New York, NY, USA, 2015; Volume 16301, pp. 1-35.

39. WHO. First WHO Global Conference on Air Pollution and Health-Ambient Air Quality Monitoring, Modelling and Forecasting; WHO: Geneva, Switzerland, 2018.

40. UNEP. Preventing and Reducing Air Pollution to Improve Air Quality Globally (Resolution Adopted at the 2017 UN Environment Assembly). Available online: https:/ / www.ccacoalition.org/en/resources/preventing-and-reducing-air-pollution-improveair-quality-globally-resolution-adopted-2017 (accessed on 9 June 2021).

41. The United Nations Environmental Assembly of the United Nations Environment Programme. Preventing and Reducing Air Pollution to Improve Air Quality Globally; UNEP: Geneva, Switzerland, 2017; Volume 6736, pp. 1-4.

42. European Commission. The European Green Deal; European Commission: Brussels, Belgium, 2019; Volume 53, p. 24.

43. European Commission. COM(2021) 400 Final: Pathway to a Healthy Planet for All-EU Action Plan: 'Towards Zero Pollution for Air, Water and Soil; European Commission: Brussels, Belgium, 2021.

44. Climate and Clean Air Coalition the Coalition. Available online: https://www.ccacoalition.org/en/content/coalition (accessed on 11 June 2021).

45. WHO; CCAC; UNEP; WB. Breathlife Campaign. Available online: https://breathelife2030.org/about/ (accessed on 9 June 2021).

46. Liang, C.-S.; Duan, F.-K.; He, K.-B.; Ma, Y.-L. Review on recent progress in observations, source identifications and countermeasures of $\mathrm{PM}_{2.5}$. Environ. Int. 2016, 86, 150-170. [CrossRef]

47. European Environment Agency (EEA). Assessment of Ground-Level Ozone in Eea Member Countries, with A Focus on Long-Term Trends; European Environment Agency (EEA): Copenhagen, Denmark, 2009.

48. Dominković, D.F.; Dobravec, V.; Jiang, Y.; Nielsen, P.S.; Krajačić, G. Modelling smart energy systems in tropical regions. Energy 2018, 155, 592-609. [CrossRef]

49. Böhm, M.; Salem, M.Z.M.; Srba, J. Formaldehyde emission monitoring from a variety of solid wood, plywood, blockboard and flooring products manufactured for building and furnishing materials. J. Hazard. Mater. 2012, 221-222, 68-79. [CrossRef]

50. Chiesa, M.; Perrone, M.G.; Cusumano, N.; Ferrero, L.; Sangiorgi, G.; Bolzacchini, E.; Lorenzoni, A.; Ballarin Denti, A. An environmental, economical and socio-political analysis of a variety of urban air-pollution reduction policies for primary $\mathrm{PM}_{10}$ and $\mathrm{NO}_{\mathrm{x}}$ : The case study of the Province of Milan (Northern Italy). Environ. Sci. Policy 2014, 44, 39-50. [CrossRef]

51. Kunkel, D.A.; Gall, E.T.; Siegel, J.A.; Novoselac, A.; Morrison, G.C.; Corsi, R.L. Passive reduction of human exposure to indoor ozone. Build. Environ. 2010, 45, 445-452. [CrossRef]

52. He, Z.; Zhang, Y.; Wei, W. Formaldehyde and VOC emissions at different manufacturing stages of wood-based panels. Build. Environ. 2012, 47, 197-204. [CrossRef]

53. Mukherjee, A.; Agrawal, M. World air particulate matter: Sources, distribution and health effects. Environ. Chem. Lett. 2017, 15, 283-309. [CrossRef]

54. WHO. Ambient (Outdoor) Air Pollution. Available online: https://www.who.int/en/news-room/fact-sheets/detail/ambient(outdoor)-air-quality-and-health (accessed on 11 June 2021).

55. Fazli, T.; Stephens, B. Development of a nationally representative set of combined building energy and indoor air quality models for U.S. residences. Build. Environ. 2018, 136, 198-212. [CrossRef]

56. Steinemann, A.; Wargocki, P.; Rismanchi, B. Ten questions concerning green buildings and indoor air quality. Build. Environ. 2017, 112, 351-358. [CrossRef]

57. Cecchi, T. Identification of representative pollutants in multiple locations of an Italian school using solid phase micro extraction technique. Build. Environ. 2014, 82, 655-665. [CrossRef]

58. Kumar, P.; Skouloudis, A.N.; Bell, M.; Viana, M.; Carotta, M.C.; Biskos, G.; Morawska, L. Real-time sensors for indoor air monitoring and challenges ahead in deploying them to urban buildings. Sci. Total Environ. 2016, 560-561, 150-159. [CrossRef] [PubMed]

59. Tham, K.W. Indoor air quality and its effects on humans-A review of challenges and developments in the last 30 years. Energy Build. 2016, 130, 637-650. [CrossRef]

60. Yu, C.; Kim, J. Building Pathology, Investigation of Sick Buildings-VOC Emissions. Indoor Built Environ. 2010, 19, 30-39. [CrossRef]

61. U.S. Environmental Protection Agency, Environments Division. Indoor Air Facts No. 4 Sick Building Syndrome; EPA-Air Radiation (6609J); Research and Development (MD-56); Environmental Protection Agency: Washington, DC, USA, 1991; pp. 1-4.

62. WHO. Household Air Pollution and Health. Available online: https://www.who.int/news-room/fact-sheets/detail/householdair-pollution-and-health (accessed on 12 June 2021).

63. Amato, F.; Rivas, I.; Viana, M.; Moreno, T.; Bouso, L.; Reche, C.; Àlvarez-Pedrerol, M.; Alastuey, A.; Sunyer, J.; Querol, X. Sources of indoor and outdoor $\mathrm{PM}_{2.5}$ concentrations in primary schools. Sci. Total Environ. 2014, 490, 757-765. [CrossRef] [PubMed] 
64. Canha, N.; Almeida, S.M.; do Carmo Freitas, M.; Wolterbeek, H.T.; Cardoso, J.; Pio, C.; Caseiro, A. Impact of wood burning on indoor $\mathrm{PM}_{2.5}$ in a primary school in rural Portugal. Atmos. Environ. 2014, 94, 663-670. [CrossRef]

65. Wargocki, P.; Wyon, D.P. Providing better thermal and air quality conditions in school classrooms would be cost-effective. Build. Environ. 2013, 59, 581-589. [CrossRef]

66. Li, C.Z.; Zhao, Y.; Xu, X. Investigation of dust exposure and control practices in the construction industry: Implications for cleaner production. J. Clean. Prod. 2019, 227, 810-824. [CrossRef]

67. Li, N.; Long, X.; Tie, X.; Cao, J.; Huang, R.; Zhang, R.; Feng, T.; Liu, S.; Li, G. Urban dust in the Guanzhong basin of China, part II: A case study of urban dust pollution using the WRF-Dust model. Sci. Total Environ. 2016, 541, 1614-1624. [CrossRef]

68. Chang, Y.-M.; Hu, W.-H.; Su, K.-T.; Chou, C.-M.; Kao, C.M.; Lin, K.-L. PM 10 Emissions Reduction from Exposed Areas Using Grass-Planted Covering: Field Study of a Construction Site. J. Environ. Eng. 2014, 140, 6014006. [CrossRef]

69. De Moraes, R.J.B.; Costa, D.B.; Priscylla, I.; Araújo, S. Particulate Matter Concentration from Construction Sites: Concrete and Masonry Works; ASCE: Reston, VA, USA, 2011; pp. 1-11. [CrossRef]

70. Hassan, H.A.; Kumar, P.; Kakosimos, K.E. Flux estimation of fugitive particulate matter emissions from loose Calcisols at construction sites. Atmos. Environ. 2016, 141, 96-105. [CrossRef]

71. CEN EN 15804:2012+A2:2019 Sustainability of Construction Works-Environmental Product Declarations—Core Rules for the Product Category of Construction Products; National Standards Authority of Ireland: Dublin, Ireland, 2019; p. 72.

72. CEN EN 15978:2011 Sustainability of Construction Works—Assessment of Environmental Performance of Buildings—Calculation Method; National Standards Authority of Ireland: Dublin, Ireland, 2011; p. 60.

73. European Parliament. EU Policy on Air Quality: Implementation of Selected EU Legislation; European Parliament: Brussels, Belgium, 2021; ISBN 978-92-846-7683-5.

74. Prada, M.; Prada, I.F.; Cristea, M.; Popescu, D.E.; Bungău, C.; Aleya, L.; Bungău, C.C. New solutions to reduce greenhouse gas emissions through energy efficiency of buildings of special importance-Hospitals. Sci. Total Environ. 2020, 718, 137446. [CrossRef]

75. European Parliament. Directive 2010/31/EU of the European Parliament and of the Council of 19 May 2010 on the Energy Performance of Buildings; European Parliament and Council: Strasbourg, France, 2010.

76. Milner, J.; Vardoulakis, S.; Chalabi, Z.; Wilkinson, P. Modelling inhalation exposure to combustion-related air pollutants in residential buildings: Application to health impact assessment. Environ. Int. 2011, 37, 268-279. [CrossRef]

77. Che, W.W.; Tso, C.Y.; Sun, L.; Ip, D.Y.K.; Lee, H.; Chao, C.Y.H.; Lau, A.K.H. Energy consumption, indoor thermal comfort and air quality in a commercial office with retrofitted heat, ventilation and air conditioning (HVAC) system. Energy Build. 2019, 201, 202-215. [CrossRef]

78. Cheng, S.; Chen, D.; Li, J.; Wang, H.; Guo, X. The assessment of emission-source contributions to air quality by using a coupled MM5-ARPS-CMAQ modeling system: A case study in the Beijing metropolitan region, China. Environ. Model. Softw. 2007, 22, 1601-1616. [CrossRef]

79. Zhao, Y.; Chen, B.; Guo, Y.; Peng, F.; Zhao, J. Indoor air environment of residential buildings in Dalian, China. Energy Build. 2004, 36, 1235-1239. [CrossRef]

80. Parhizkar, H.; Khoraskani, R.A.; Tahbaz, M. Double skin façade with Azolla; ventilation, Indoor Air Quality and Thermal Performance Assessment. J. Clean. Prod. 2020, 249, 119313. [CrossRef]

81. Thevenet, F.; Debono, O.; Rizk, M.; Caron, F.; Verriele, M.; Locoge, N. VOC uptakes on gypsum boards: Sorption performances and impact on indoor air quality. Build. Environ. 2018, 137, 138-146. [CrossRef]

82. Zanoletti, A.; Bilo, F.; Federici, S.; Borgese, L.; Depero, L.E.; Ponti, J.; Valsesia, A.; La Spina, R.; Segata, M.; Montini, T.; et al. The first material made for air pollution control able to sequestrate fine and ultrafine air particulate matter. Sustain. Cities Soc. 2020, 53, 101961. [CrossRef]

83. Bungău, C.C.; Prada, I.F.; Prada, M.; Bungău, C. Design and Operation of Constructions: A Healthy Living EnvironmentParametric Studies and New Solutions. Sustainability 2019, 11, 6824. [CrossRef]

84. Ng, W.Y.; Chau, C.K. New Life of the Building Materials-Recycle, Reuse and Recovery. Energy Procedia 2015, 75, $2884-2891$. [CrossRef]

85. Sigrid Nordby, A. Barriers and opportunities to reuse of building materials in the Norwegian construction sector. IOP Conf. Ser. Earth Environ. Sci. 2019, 225, 12061. [CrossRef]

86. Dassonville, C.; Demattei, C.; Laurent, A.-M.; Moullec, Y.; Seta, N.; Momas, I. Assessment and predictor determination of indoor aldehyde levels in Paris newborn babies' homes. Indoor Air 2009, 19, 314-323. [CrossRef]

87. Derbez, M.; Berthineau, B.; Cochet, V.; Pignon, C.; Ribéron, J.; Wyart, G.; Mandin, C.; Kirchner, S. A 3-year follow-up of indoor air quality and comfort in two energy-efficient houses. Build. Environ. 2014, 82, 288-299. [CrossRef]

88. Font, A.; Baker, T.; Mudway, I.S.; Purdie, E.; Dunster, C.; Fuller, G.W. Degradation in urban air quality from construction activity and increased traffic arising from a road widening scheme. Sci. Total Environ. 2014, 497-498, 123-132. [CrossRef]

89. Giunta, M. Assessment of the environmental impact of road construction: Modelling and prediction of fine particulate matter emissions. Build. Environ. 2020, 176, 106865. [CrossRef]

90. Giunta, M.; Lo Bosco, D.; Leonardi, G.; Scopelliti, F. Estimation of Gas and Dust Emissions in Construction Sites of a Motorway Project. Sustainability 2019, 11, 7218. [CrossRef] 
91. Thai, A.; McKendry, I.; Brauer, M. Particulate matter exposure along designated bicycle routes in Vancouver, British Columbia. Sci. Total Environ. 2008, 405, 26-35. [CrossRef]

92. Yan, H.; Ding, G.; Li, H.; Wang, Y.; Zhang, L.; Shen, Q.; Feng, K. Field Evaluation of the Dust Impacts from Construction Sites on Surrounding Areas: A City Case Study in China. Sustainability 2019, 11, 1906. [CrossRef]

93. Kim, S.-S.; Kang, D.-H.; Choi, D.-H.; Yeo, M.-S.; Kim, K.-W. Comparison of strategies to improve indoor air quality at the pre-occupancy stage in new apartment buildings. Build. Environ. 2008, 43, 320-328. [CrossRef]

94. Tang, X.; Ughetta, L.; Shannon, S.K.; Houzé de l'Aulnoit, S.; Chen, S.; Gould, R.A.T.; Russell, M.L.; Zhang, J.; Ban-Weiss, G.; Everman, R.L.A.; et al. De-pollution efficacy of photocatalytic roofing granules. Build. Environ. 2019, 160, 106058. [CrossRef]

95. Bossa, N.; Chaurand, P.; Levard, C.; Borschneck, D.; Miche, H.; Vicente, J.; Geantet, C.; Aguerre-Chariol, O.; Michel, F.M.; Rose, J. Environmental exposure to $\mathrm{TiO}_{2}$ nanomaterials incorporated in building material. Environ. Pollut. 2017, 220, 1160-1170. [CrossRef] [PubMed]

96. Bai, Z.; Dong, Y.; Wang, Z.; Zhu, T. Emission of ammonia from indoor concrete wall and assessment of human exposure. Environ. Int. 2006, 32, 303-311. [CrossRef] [PubMed]

97. Schripp, T.; Langer, S.; Salthammer, T. Interaction of ozone with wooden building products, treated wood samples and exotic wood species. Atmos. Environ. 2012, 54, 365-372. [CrossRef]

98. George, C.; Beeldens, A.; Barmpas, F.; Doussin, J.-F.; Manganelli, G.; Herrmann, H.; Kleffmann, J.; Mellouki, A. Impact of photocatalytic remediation of pollutants on urban air quality. Front. Environ. Sci. Eng. 2016, 10, 2. [CrossRef]

99. Hutter, H.-P.; Moshammer, H.; Wallner, P.; Damberger, B.; Tappler, P.; Kundi, M. Health complaints and annoyances after moving into a new office building: A multidisciplinary approach including analysis of questionnaires, air and house dust samples. Int. J. Hyg. Environ. Health 2006, 209, 65-68. [CrossRef]

100. Du, T.; Sun, Y. Correlation of Building Heating and Air Qualities in Typical Cities of China. Energy Procedia 2019, 158, 6532-6537. [CrossRef]

101. Sun, Y.; Wang, P.; Zhang, Q.; Ma, H.; Hou, J.; Kong, X. Indoor Air Pollution and Human Perception in Public Buildings in Tianjin, China. Procedia Eng. 2015, 121, 552-557. [CrossRef]

102. Shaw, C.; Boulic, M.; Longley, I.; Mitchell, T.; Pierse, N.; Howden-Chapman, P. The association between indoor and outdoor $\mathrm{NO}_{2}$ levels: A case study in 50 residences in an urban neighbourhood in New Zealand. Sustain. Cities Soc. 2020, 56, 102093. [CrossRef]

103. Fan, S.; Wong, Y.; Shen, L.; Lu, W.; Wang, T.; Yu, A.; Shen, Q. The effectiveness of DustBubbles on dust control in the process of concrete drilling. Saf. Sci. 2012, 50, 1284-1289. [CrossRef]

104. Faber, P.; Drewnick, F.; Borrmann, S. Aerosol particle and trace gas emissions from earthworks, road construction, and asphalt paving in Germany: Emission factors and influence on local air quality. Atmos. Environ. 2015, 122, 662-671. [CrossRef]

105. Fuller, G.W.; Green, D. The impact of local fugitive $\mathrm{PM}_{10}$ from building works and road works on the assessment of the European Union Limit Value. Atmos. Environ. 2004, 38, 4993-5002. [CrossRef]

106. Gabbe, C.J.; Oxlaj, E.; Wang, J. Residential development and near-roadway air pollution: Assessing risk and mitigation in San Jose, California. J. Transp. Health 2019, 13, 78-89. [CrossRef]

107. Wang, Y.; Chen, C.; Wang, P.; Wan, Y.; Chen, Z.; Zhao, L. Experimental Investigation on Indoor/Outdoor PM 2.5 Concentrations of an Office Building Located in Guangzhou. Procedia Eng. 2015, 121, 333-340. [CrossRef]

108. Jing, R.; Wang, M.; Brandon, N.; Zhao, Y. Multi-criteria evaluation of solid oxide fuel cell based combined cooling heating and power (SOFC-CCHP) applications for public buildings in China. Energy 2017, 141, 273-289. [CrossRef]

109. Aung, W.-Y.; Noguchi, M.; Pan-Nu Yi, E.-E.; Thant, Z.; Uchiyama, S.; Win-Shwe, T.-T.; Kunugita, N.; Mar, O. Preliminary assessment of outdoor and indoor air quality in Yangon city, Myanmar. Atmos. Pollut. Res. 2019, 10, 722-730. [CrossRef]

110. Rella, R.; Sturaro, A.; Vianello, A. Incorrect installation and use of materials as the cause of a severe air pollution incident in a school building. Sci. Total Environ. 2014, 487, 255-259. [CrossRef]

111. Vervoort, R.; Blocken, B.; van Hooff, T. Reduction of particulate matter concentrations by local removal in a building courtyard: Case study for the Delhi American Embassy School. Sci. Total Environ. 2019, 686, 657-680. [CrossRef]

112. Kozlovtseva, E.Y.; Loboyko, V.F.; Nikolenko, D.A. Monitoring of Fine Dust Pollution of Multistory Buildings Air Environment as an Adoption Factor of Town-planning Decisions. Procedia Eng. 2016, 150, 1954-1959. [CrossRef]

113. Bozkurt, Z.; Doğan, G.; Arslanbaş, D.; Pekey, B.; Pekey, H.; Dumanoglu, Y.; Bayram, A.; Tuncel, G. Determination of the personal, indoor and outdoor exposure levels of inorganic gaseous pollutants in different microenvironments in an industrial city. Environ. Monit. Assess. 2015, 187, 4816. [CrossRef]

114. Chan, C.Y.; Xu, X.D.; Li, Y.S.; Wong, K.H.; Ding, G.A.; Chan, L.Y.; Cheng, X.H. Characteristics of vertical profiles and sources of $\mathrm{PM}_{2.5}, \mathrm{PM}_{10}$ and carbonaceous species in Beijing. Atmos. Environ. 2005, 39, 5113-5124. [CrossRef]

115. Heidari, B.; Marr, L. Real-time emissions from construction equipment compared with model predictions. J. Air Waste Manag. Assoc. 2015, 65. [CrossRef]

116. Schleicher, N.; Norra, S.; Dietze, V.; Yu, Y.; Fricker, M.; Kaminski, U.; Chen, Y.; Cen, K. The effect of mitigation measures on size distributed mass concentrations of atmospheric particles and black carbon concentrations during the Olympic Summer Games 2008 in Beijing. Sci. Total Environ. 2011, 412-413, 185-193. [CrossRef] [PubMed]

117. Alvanchi, A.; Rahimi, M.; Mousavi, M.; Alikhani, H. Construction schedule, an influential factor on air pollution in urban infrastructure projects. J. Clean. Prod. 2020, 255, 120222. [CrossRef] 
118. Liu, Y.-S.; Cao, Y.; Hou, J.-J.; Zhang, J.-T.; Yang, Y.-O.; Liu, L.-C. Identifying common paths of $\mathrm{CO}_{2}$ and air pollutants emissions in China. J. Clean. Prod. 2020, 256, 120599. [CrossRef]

119. Azuma, K.; Ikeda, K.; Kagi, N.; Yanagi, U.; Osawa, H. Physicochemical risk factors for building-related symptoms in airconditioned office buildings: Ambient particles and combined exposure to indoor air pollutants. Sci. Total Environ. 2018, 616-617, 1649-1655. [CrossRef] [PubMed]

120. Asere, L.; Mols, T.; Blumberga, A. Assessment of Energy Efficiency Measures on Indoor Air Quality and Microclimate in Buildings of Liepaja Municipality. Energy Procedia 2016, 95, 37-42. [CrossRef]

121. Spiru, P.; Simona, P.L. A review on interactions between energy performance of the buildings, outdoor air pollution and the indoor air quality. Energy Procedia 2017, 128, 179-186. [CrossRef]

122. Jiang, C.; Li, D.; Zhang, P.; Li, J.; Wang, J.; Yu, J. Formaldehyde and volatile organic compound (VOC) emissions from particleboard: Identification of odorous compounds and effects of heat treatment. Build. Environ. 2017, 117, 118-126. [CrossRef]

123. Šenitková, I.J.; Kraus, M. Assessment of Selected Interior Flooring Materials on Indoor Air Quality. Procedia Eng. 2016, 161, 1527-1531. [CrossRef]

124. Khodakarami, J.; Ghobadi, P. Urban pollution and solar radiation impacts. Renew. Sustain. Energy Rev. 2016, 57, 965-976. [CrossRef]

125. Asim, N.; Alghoul, M.; Mohammad, M.; Amin, M.H.; Akhtaruzzaman, M.; Amin, N.; Sopian, K. Emerging sustainable solutions for depollution: Geopolymers. Constr. Build. Mater. 2019, 199, 540-548. [CrossRef]

126. Guttikunda, S.K.; Goel, R.; Pant, P. Nature of air pollution, emission sources, and management in the Indian cities. Atmos. Environ. 2014, 95, 501-510. [CrossRef]

127. Juda-Rezler, K.; Reizer, M.; Maciejewska, K.; Błaszczak, B.; Klejnowski, K. Characterization of atmospheric PM2.5 sources at a Central European urban background site. Sci. Total Environ. 2020, 713, 136729. [CrossRef] [PubMed]

128. Ahmed, S.; Arocho, I. Emission of particulate matters during construction: A comparative study on a Cross Laminated Timber (CLT) and a steel building construction project. J. Build. Eng. 2019, 22, 281-294. [CrossRef]

129. Guttikunda, S.K.; Nishadh, K.A.; Gota, S.; Singh, P.; Chanda, A.; Jawahar, P.; Asundi, J. Air quality, emissions, and source contributions analysis for the Greater Bengaluru region of India. Atmos. Pollut. Res. 2019, 10, 941-953. [CrossRef]

130. Järnström, H.; Saarela, K.; Kalliokoski, P.; Pasanen, A.-L. Reference values for indoor air pollutant concentrations in new, residential buildings in Finland. Atmos. Environ. 2006, 40, 7178-7191. [CrossRef]

131. Guariso, G.; Sangiorgio, M. Multi-objective planning of building stock renovation. Energy Policy 2019, 130, 101-110. [CrossRef]

132. Tunno, B.; Longley, I.; Somervell, E.; Edwards, S.; Olivares, G.; Gray, S.; Cambal, L.; Chubb, L.; Roper, C.; Coulson, G.; et al. Separating spatial patterns in pollution attributable to woodsmoke and other sources, during daytime and nighttime hours, in Christchurch, New Zealand. Environ. Res. 2019, 171, 228-238. [CrossRef]

133. Tong, Z.; Yang, B.; Hopke, P.K.; Zhang, K.M. Microenvironmental air quality impact of a commercial-scale biomass heating system. Environ. Pollut. 2017, 220, 1112-1120. [CrossRef]

134. Shafique, M.; Xue, X.; Luo, X. An overview of carbon sequestration of green roofs in urban areas. Urban For. Urban Green. 2020, 47, 126515. [CrossRef]

135. Karteris, M.; Theodoridou, I.; Mallinis, G.; Tsiros, E.; Karteris, A. Towards a green sustainable strategy for Mediterranean cities: Assessing the benefits of large-scale green roofs implementation in Thessaloniki, Northern Greece, using environmental modelling, GIS and very high spatial resolution remote sensing data. Renew. Sustain. Energy Rev. 2016, 58, 510-525. [CrossRef]

136. Muir, D.; Longhurst, J.W.S.; Tubb, A. Characterisation and quantification of the sources of $\mathrm{PM}_{10}$ during air pollution episodes in the UK. Sci. Total Environ. 2006, 358, 188-205. [CrossRef]

137. Saliba, N.A.; El Jam, F.; El Tayar, G.; Obeid, W.; Roumie, M. Origin and variability of particulate matter $\left(\mathrm{PM}_{10}\right.$ and $\left.\mathrm{PM}_{2.5}\right) \mathrm{mass}$ concentrations over an Eastern Mediterranean city. Atmos. Res. 2010, 97, 106-114. [CrossRef]

138. Wieser, A.A.; Scherz, M.; Maier, S.; Passer, A.; Kreiner, H. Implementation of Sustainable Development Goals in construction industry-A systemic consideration of synergies and trade-offs. IOP Conf. Ser. Earth Environ. Sci. 2019, 323, 012177. [CrossRef]

139. Scherz, M.; Zunk, B.M.; Passer, A.; Kreiner, H. Visualizing interdependencies between sustainability criteria to support multicriteria decision-making processes in building design. Procedia CIRP 2018, 69, 200-205. [CrossRef]

140. Kreiner, H.; Scherz, M.; Passer, A. How to make decision-makers aware of sustainable construction? In Proceedings of the Life-Cycle Analysis and Assessment in Civil Engineering, Ghent, Belgium, 28-31 October 2018; Caspeele, R., Taerwe, L., Frangopol, D., Eds.; CRC Press: Boca Raton, FL, USA, 2018.

141. Scherz, M.; Passer, A.; Kreiner, H. Challenges in the achievement of a Net Zero Carbon Built Environment-A systemic approach to support the decision-aiding process in the design stage of buildings. IOP Conf. Ser. Earth Environ. Sci. 2020, $588,32034$. [CrossRef]

142. Körfgen, A.; Glatz, I.; Maier, S.; Scherz, M.; Kreiner, H.; Passer, A.; Allerberger, F.; Kromp-Kolb, H.; Stötter, J. Austrian Universities and the Sustainable Development Goals. IOP Conf. Ser. Earth Environ. Sci. 2019, 323, 012156. [CrossRef] 